\title{
The fishes of the Nam Theun and Xe Bangfai drainages, Laos
}

\author{
Les poissons des bassins de la Nam Theun et de la Xe Bangfai, \\ Laos
}

\section{Kottelat}

Aquatic biodiversity specialist, rue des Rauraques 6, 2800 Delémont, Switzerland mkottelat@dplanet.ch

\begin{abstract}
The fish diversity of the Nam Theun and Xe Bangfai drainages was surveyed between 1996 and 2012. 74 species are now recorded from the Nam Theun and 178 from the Xe Bangfai drainages. Twenty-one (28\%) of the Nam Theun species are endemic and 9 $(5 \%)$ of the Xe Bangfai species. At the time of the respective surveys, 54 species were new records for Laos, and 25 species were new to science. While the fish fauna of Xe Bangfai is similar to that of the other main tributaries of the Mekong in Laos, the fish fauna of the Nam Theun is characterised by a great proportion of endemics, several of which have affinities with species known from the opposite slope of the Annamite Range, in Vietnam. Besides, work conducted in relation with aquatic biodiversity surveys for the Nam Theun 2 project resulted in an increase of the fish fauna of Laos from 210 to 481 in 3 years between March 1996 and June 1999 and the discovery of 128 species new to science and lead to the publication of an identification guide. Specific studies have been conducted to assess the status of some of the endemic species that were potentially threatened by the Nam Theun 2 scheme: Scaphognathops theunensis (still observed in 2012 downstream of Nakai Dam), Tor ater (mainly restricted to streams upstream of the reservoir), and Oryzias sp. 'swamp' (along the fringe of the reservoir). The status of the bitterling Rhodeus laoensis and its associated mussel is still not clear. Most of the species endemic to the Nam Theun drainage are known upstream of the reservoir, which is a protected area. The endemic species known on Nakai Plateau and downstream of the dam are more at risk and require closer monitoring.
\end{abstract}

Key words - fish diversity, Mekong tributaries, endemism, hydropower project

Résumé - La diversité ichtyologique des bassins de la Nam Theun et de la Xe Bangfai a été suivie entre 1996 et 2012. 74 espèces sont maintenant recensées pour le bassin de la Nam Theun et 178 pour le bassin de la Xe Bangfai. Vingt-et-une (28 \%) des espèces de la Nam Theun y sont endémiques et $9(5 \%)$ de celles de la Xe Bangfai. Au moment des inventaires respectifs, 54 espèces ont été ajoutées à la liste des espèces connues au Laos, et 25 espèces étaient nouvelles pour la science. Alors que la faune ichtyologique de la Xe Bangfai est similaire à celle des autres principaux affluents du Mékong au Laos, la Nam Theun est caractérisée 
par une grande proportion d'espèces endémiques, plusieurs de ces espèces présentant des affinités avec les espèces connues du versant opposé de la chaîne annamitique, au Vietnam. De plus, les travaux d'inventaire de la biodiversité aquatique conduits en relation avec le projet de Nam Theun 2 ont fait passer la faune ichtyologique du Laos de 210 à 481 espèces en 3 ans entre mars 1996 et juin 1999 ; ils ont mené à la découverte de 128 espèces nouvelles pour la science et à la publication d'un guide d'identification. Des études spécifiques ont été conduites afin d'évaluer le statut de quelques espèces endémiques potentiellement menacées par le projet hydroélectrique de Nam Theun 2 : Scaphognathops theunensis (encore observée à l'aval du barrage en 2012), Tor ater (restreinte principalement aux affluents en amont du réservoir), et Oryzias sp. 'swamp' (sur les bords du réservoir). Le statut de la bouvière Rhodeus laoensis et de la moule associée à son cycle biologique n'est pas encore clarifié. La plupart des espèces endémiques de la Nam Theun sont connues en amont du réservoir, qui est une zone protégée. Les espèces endémiques connues du plateau de Nakai et en aval du réservoir sont plus menacées et nécessitent un suivi attentif.

Mots clés - diversité ichtyologique, affluents du Mékong, endémisme, projet hydroélectrique

\section{INTRODUCTION}

The diversity of inland fishes in Southeast Asia is very high, with about 3000 named species (Kottelat, 2013b). Despite this high diversity and their importance for humans, our knowledge of fish biology over most of Asia is still very incomplete and often is restricted to mere lists (Kottelat \& Whitten, 1996). Large areas are still unsurveyed.

In a review of the conservation status of fish in mainland Southeast Asia, Kottelat et al. (2012a) reviewed the major threats affecting freshwater fishes. They found that alteration of river morphology is the single most important threat since it modifies or suppresses the habitats and the hydrological features upon which the fish depend. Among these alterations, the development of dams and reservoirs is the most crucial threat.

A number of the impacts are intrinsic to the creation of reservoirs, like the suppression of a part of the habitats in the reservoir and downstream of a dam or downstream of a diversion channel, or the interruption of migratory road, and must be addressed and mitigated at the conception of the project. In areas whose fish fauna is still superficially known (as is the case in most of Laos), extensive surveys and collection of baseline data is an absolute necessity. The surveys should not be restricted to the directly impacted area but must include adjacent areas, in as well as outside the impacted river system.

The information on Laotian fishes published in the scientific literature is still very limited. Proper scientific surveys of the fish diversity started in the mid-1990s in conjunction with hydropower development. Without underestimating the environmental impacts of the project, surveys conducted in the framework of the Nam Theun 2 project are unique in Laos for various extents: (i) the baseline studies that have been 
conducted before construction, (ii) the quantity of information that have been assembled, made publicly accessible and that have been used for scientific research.

This essay briefly presents the researches that have been conducted between 1996 and 2012, the fish fauna of the Nam Theun and Xe Bangfai drainages and the status of the species of special concern.

\section{METHODS AND TERMINOLOGY}

Over the years, fish samples were obtained with almost all possible methods: electricity, gill nets, castnets, seines, pushnets, kicknets, hook and line, traps, spears, and ichthyocides. Explosives were never used although fishes killed by poachers have occasionally been observed. All possible existing habitats have been surveyed, including headwaters, riffles, runs, deep pools, main rivers, waterfalls, rapids, swamps, lakes and caves. Sampling sites of very difficult accesses, up in the Annamite range or in the gorges were reached by helicopter. Surveys were conducted in 1996, 2002, 2003, 2006, 2007, 2009, 2011 and 2012. Samples were obtained at 243 sites; most sites were sampled once, but some were sampled by up to 5 surveys.

Species are recorded only under their scientific names (see Kottelat, $2013 \mathrm{~b}$ for the latest update of the nomenclature of the fishes of freshwaters in Southeast Asia). The term "sp." means an unidentified species. The term "aff." means that a population cannot be identified with any known species but is close to a named species (for example Microcobitis aff. misgurnoides is distinct but close to Microcobitis misgurnoides. The term "cf." indicates that the population is likely to belong to the species referred to but the identification is not yet certain because of unresolved taxonomic problems.

In the discussion, endemic is used as either a noun or an adjective means: whose distribution is restricted to a geographically limited area. For example, a species endemic to the Nam Theun is a species that has been observed only in the Nam Theun drainage.

Spelling of names of villages, mountains, and streams follow either the NTPC standard toponymy or the 1985 1:100,000 Lao P.D.R. topographic maps. Coordinates were obtained from maps in the early years and with a variety of GPS after 2000. Datum: WGS 84, UTM zone 48.

Limitations. Ideally, we should be able to select more or less random sites for survey. This is rarely feasible for different reasons, among which: (i) the places were the river is accessible by land may not be suitable for sampling; (ii) it may be impossible to land by boat at a given site; (iii) the presence of a village or a fishing camp does not allow the use of some methods; (iv) or the available equipment does not allow good sampling of large rivers or deep waters, or very fast current. These limitations are most obvious for the work in the lower Nam Theun (downstream of the Nakai Dam), several stretches of which can only be accessed by helicopter (as done in 1996, 2006 and 2007) or by long walks along dangerous shores, which is not possible with heavy equipment. The number of places allowing a safe access to the river is limited, and 
then one needs to be able to safely move around, to find a spot where it is possible to set (and recover) nets, to apply chemicals, to recover the samples. Safety is a very important limitation because of the very strong current, slippery rocks, etc.

Conventions. Upper Nam Theun refers to the Nam Theun River upstream of the Nakai Reservoir. Lower Nam Theun refers to the Nam Theun River downstream of the Nakai Dam.

Keng Louang: in Laos, most rapids have a proper name, and on many rivers there is one or more called Keng Louang (literally "large rapids"). The Nam Theun has two Keng Louang, one far downstream of the reservoir, the other at about FSL (Full Supply Level). The Nam Xot has one Keng Louang, below FSL.

NPA stands for National Protected Area, as used here it implies the Nakai-Nam Theun NPA.

$S L$ stands for standard length (the length of a fish without the caudal fin); mas/ for meters above sea level.

\section{FISH SURVEYS: CHRONOLOGY AND SIGNIFICANCE OF NAM THEUN 2 PROJECT ON KNOWLEDGE OF LAOTIAN FISH FAUNA}

The first mention of fishes of Laos in the scientific literature dates back to 1878 when Sauvage $(1878,1880)$ described a few fishes collected by Jules Harmand (Kottelat, 1984).

Nothing else was published until the 1930s, when some fishes were collected during ornithological expeditions by J. Delacour (Hennache \& Dickinson, 2000; Kottelat, 2012c: 51) and described by Pellegrin (1936) and Pellegrin \& Fang (1940).

Sérène (1951) compiled a first list of the fishes of Laos and Taki (1974) published a book summarising the known fauna and its distribution. However, the published scientific data on fish distribution and biology were virtually restricted to the Mekong mainstream (Kottelat, 1989; Roberts, 1993). Except for limited data on the Nam Ngum 1 Reservoir and isolated descriptions of new species there was no data on the fish fauna of the tributaries and headwaters.

A first survey of the fishes of the Nam Theun and Xe Bangfai was very superficial, with about 54 species observed, with numerous identification problems.

As of March 1996, about 210 fish species were known from Laos. The first survey of the fishes of the Nam Theun and Xe Bangfai yielded 165 species (Kottelat, 1996), which is equal to $79 \%$ of what was known before for the whole country. In fact 46 of these species had not been recorded before in the country. In one month the fish fauna of Laos had increased to 256 species. Several of these 46 species were known from Thailand, Vietnam or China, but 16 were apparently new to science and ipso facto endemic to the Nam Theun 2 project area.

The next year, surveys were conducted in order to try to find these 16 endemics outside the project area (Kottelat, 1997). The Xe Banghiang (the drainage immediately South of the Xe Bangfai) was surveyed. For safety and logistics reason it was no possible to survey the Nam Kading and Nam Xan immediately north of the Nam 
Theun, and rivers were surveyed further North in Laos. These surveys obtained 233 fish species in 5 weeks, that is, about as many species that were already known in the country after the 1996 survey. The surveys added 55 species to the fauna of Laos, of which 35 were new to science. The surveys also discovered some of the putative endemics in the Xe Banghiang and they also allowed to show that most of the species endemic to the project area were present upstream of the impacted area.

In 1999 I was asked to compile the reports of the surveys conducted for Nam Theun 2 and other projects into a guide to the fishes of Laos. This project was supported by a grant from World Bank/Netherlands Partnership Program. In order to have a more complete coverage, several additional drainages were surveyed. These surveys as well as works of other researchers (e.g. Baird et al., 1999) brought the fish fauna of Laos to 481 species (Kottelat, 2001). From 210 species in March 1996 and to 481 in June 1999, the fish fauna of Laos had increased by $228 \%$. These surveys allowed the discovery of 128 species new to science (Kottelat, 1998, 2000; Ng \& Kottelat, 1998, 1999, 2000a-c; Ng, 1999a-b; Chen et al., 1999; Kottelat \& Bréhier, 1999; Fang \& Kottelat, 1999, 2000; Britz \& Kottelat, 1999a-b; Kottelat \& Ng, 1999; Chen \& Kottelat, 2000).

Since, species continued to be added by other surveys and other researchers and the total fish fauna of Laos is now about 520.

After the 1996 survey of Nam Theun 2 project area, Roberts (1998b, 1999) described additional species he had obtained on Nakai Plateau. The 1999 survey also found more of the 'endemic' species outside the Nam Theun 2 project area and further taxonomic research revealed that some of the species identified in 1996 were in fact a mixture of several species. In 2002, two species remained (Scaphognathops theunensis, Tor ater) that were known only from the impacted area and surveys were conducted in 2002 and 2003 to try to find them outside the impacted area and to obtain information on their biology and life cycle (Kottelat, 2002, 2004).

With the start of the construction phase of the Nam Theun 2 project, additional surveys were conducted in 2006 , 2007, 2009 and 2012 to collect baseline data and for monitoring (Kottelat, 2006, 2007, 2009, 2013a).

The surveys done in connection with the Nam Theun 2 project contributed directly or indirectly to the documentation of more than half of the fish fauna of Laos. Fish surveys have been conducted for other hydropower projects in the country. Most are not publicly available, or are not usable. Only very few other surveys produced data that resulted in scientific publications (Roberts, 1995, 1997, 1998a; Baird et al., 1999).

\section{THE STUDY AREA}

The investigated area covers the drainages of the Nam Theun and $\mathrm{Xe}$ Bangfai (Fig. 1). The Xe Bangfai is an east-side tributary of the Mekong, entering it about $50 \mathrm{~km}$ south of Thakhek. The Nam Theun is adjacent to the Xe Bangfgai to the North; it joins the Nam Gnouang to constitute the Nam 


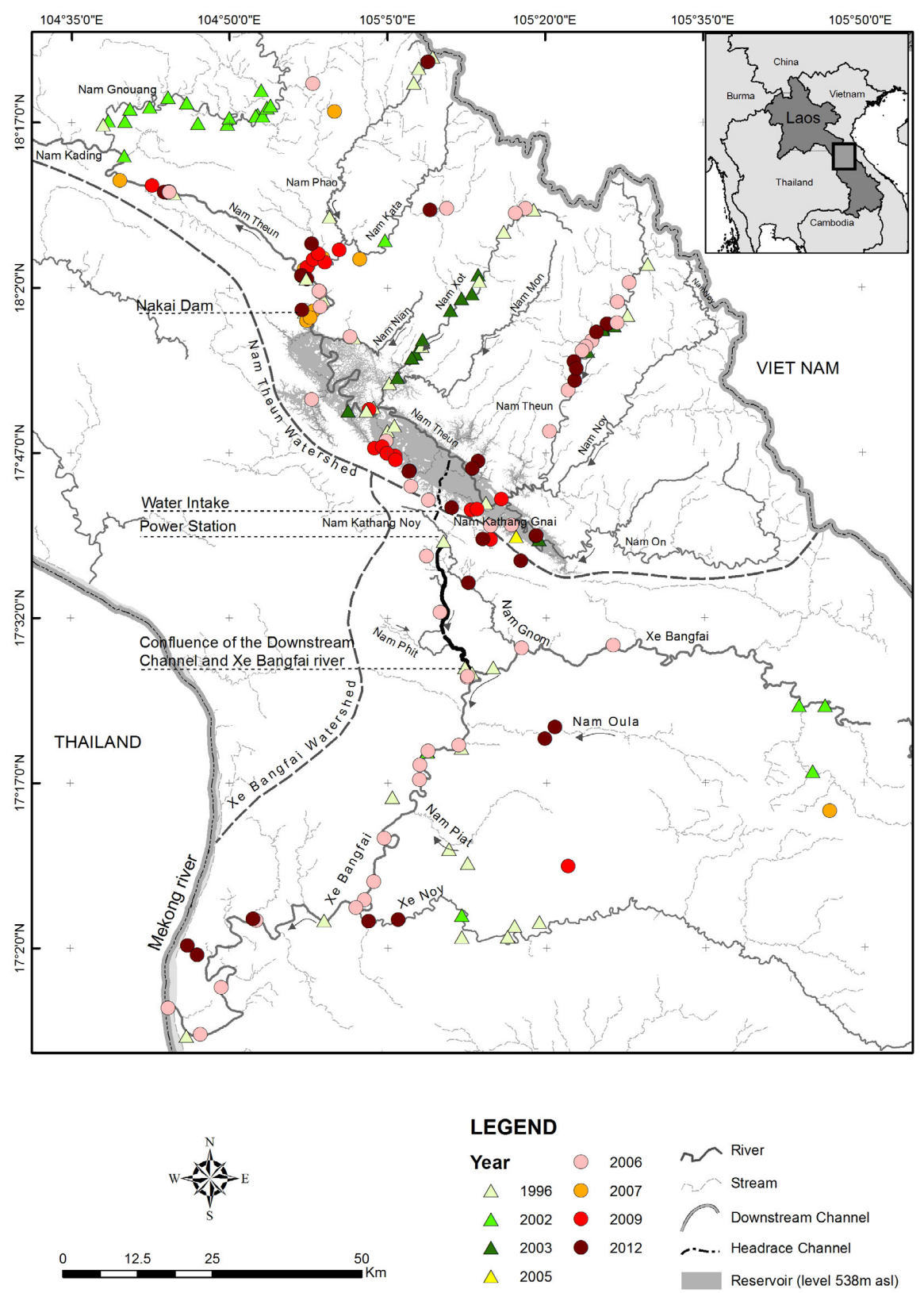

Fig. 1. Map of Nam Theun and Xe Bangfai drainages showing sites sampled by fish biodiversity surveys between 1996 and 2012.

Fig. 1. Carte des bassins de la Nam Theun et la Xe Bangfai montrant les sites échantillonnés par les inventaires ichtyologiques entre 1996 et 2012. 
Kading, another large east-side tributary of the Mekong, entering it south of Paksan. Although adjacent, the two rivers have different topography, which is reflected by different fish fauna.

\subsection{Nam Theun}

The Nam Theun and its tributaries (the main ones are Nam On, Nam Noy, Nam Mon, Nam Xot and Nam Nian) originate on the Laos-Vietnam boundary, 1000-2200 masl, and flow perpendicular to it, northeast-southwest. These rivers have a high gradient and are interrupted by many large rapids and waterfalls. Their bed is mainly made of large blocks, boulders and stones, except for a threshold of a few $\mathrm{km}$ at about 560 masl with relatively slow water, with sandy bottom and shores. From there, the Nam Theun and its tributaries descend to Nakai Plateau through deep and steep gorges, in a succession of rapids (now flooded, at least part of the year).

The Nam Theun and its tributaries flow parallel to each other until they reach Nakai Plateau. Although the plateau is quite flat (altitude about 530 masl) and has only a very shallow ridge above a steep slope directed northeast-southwest, the Nam Theun makes a sharp right angle turn northwest and is joined by its tributaries.

The Nam Theun meanders on the plateau in a succession of relatively slow runs, shallow rapids and deep pools. The substrate varies from sand (especially at mouth of tributaries, e.g. Nam Xot, Nam On) to rocks. The water was usually clear in the dry season.

An extensive area of the plateau was naturally flooded in the wet season, but in the dry season only mud pools and a few deeper lakes subsisted.

The Nam Theun leaves the Nakai Plateau through long and narrow gorges. In this stretch, until 2008, the Nam Theun was a succession of rapids and a waterfall (that disappeared in the rainy season). Along this stretch the Nam Theun receives a single tributary (Nam Phao), which also originates on the Laos-Vietnam border and also flows parallel to the other Nam Theun tributaries. The Nam Theun has no significant tributaries on the left side.

About $70 \mathrm{~km}$ after leaving the Nakai Plateau, the Nam Theun joins the Nam Gnouang (another river descending from the Laos-Vietnam divide) and they become the Nam Kading. The Nam Kading enters again gorges for about $70 \mathrm{~km}$ to reach the lowland, and then the Mekong. Shortly downstream of the confluence of the Nam Theun and Nam Gnouang, a dam created the TheunHinboun Reservoir and diverts part of the waters of the Nam Kading to the Nam Hinboun, another tributary of the Mekong; an extension dam on the Nam Gnouang stocks more water for the Theun-Hinboun Reservoir.

\subsection{Xe Bangfai}

The Xe Bangfai topography is very different from that of the Nam Theun.

The sources of the Xe Bangfai are located along the Laos-Vietnam boundary at about $17^{\circ} \mathrm{N} 106^{\circ} 30^{\prime} \mathrm{E}$. The altitude of that area is around 700 masl. It first flows southeast-northwest, in a quite narrow valley and through two deeply dissected limestone areas. It has a typical morphology of highland 
river, with a bed made of stones and boulders. It has nowhere a strong gradient and no large rapids or waterfall could be seen from the air. After about $70 \mathrm{~km}$ it disappears in a natural tunnel. The distance between the entrance of the tunnel and the resurgence is about $5 \mathrm{~km}$ at the surface. The tunnel is known to foreigners since Cupet (1900: 191, map 8). Contrary to some other natural tunnels in the Khammouane karst it has numerous waterfalls and cannot be travelled by boat or used as passage between two valleys. Nevertheless, it has been crossed as early as 1905 (Macey, 1908, 1911) and since it has been mapped and explored (Mouret et al., 1996, 1997a-b, 2010; Pollack \& Osburn, 2006; Pollack et al., 2009).

From the resurgence, the Xe Bangfai flows west until about Mahaxai, across a plain with several massives of tower karst. On this plain, before reaching the area of the Nam Theun 2 project, the Xe Bangfai was a large, relatively shallow and slow flowing river, interrupted only by a few shallow rapids. In 1996 the water was clear as far as downstream of Mahaxai; this was no longer the case in 2006, with increased human activity. Downstream of Mahaxai, the Xe Bangfai turns southwards and enters a hill range where it goes through various rapids, none of significant size, and at least one very deep pool. After the gorges, it enters the Mekong floodplain and the Mekong itself.

The Xe Bangfai has two main tributaries, the Xe Noy and Nam Oula, which are shallow slow flowing streams. On most of its course, the Xe Bangfai flows in karstic formations, which explains that it has very few surface tributaries, and that most of them are temporary or have water only in their lowermost course. Also, because of the karstic formations and the absence of surface water, most of the middle and lower Xe Bangfai drainage is characterised by large quantities of sand and dust in the dry season, a phenomenon already reported in the first published description of the area (Cupet, 1900: 185).

The karst massive is very extensive and is shared with the Xe Done and Nam Hinboun drainages and also extends to Vietnam. Beside the $\mathrm{Xe}$ Bangfai tunnel already mentioned, several streams have underground courses. Numerous caves have already been explored and a number of troglobyte animals have been discovered, including three species of fishes (Kottelat \& Bréhier, 1999; Kottelat \& Steiner, 2011; Vidthayanon \& Jarutanin, 2002).

\section{FISH FAUNA}

The species now known to occur in the Nam Theun and Xe Bangfai drainages and their distribution outside these drainages are given in Appendix 1.

\subsection{Nam Theun drainage}

Seventy-four fish species have been recorded in the Nam Theun and Nam Gnouang drainages. The two rivers join to form the Nam Kading. The fish fauna of the Nam Gnouang is still incompletely surveyed but for what is known, in the lowermost section, it is identical to that of the Nam Theun (from data of the 1996 and 2002 surveys). The fauna of the upper part of 
the Nam Gnouang drainage, however, could differ from that of the Nam Theun. More surveys may have been conducted for other projects but the data have not been made public. The list of the native species recorded in the Nam Theun is presented in Table I.

The fauna of the Nam Theun is peculiar by its high proportion of endemic species, 21 out of $74(28 \%)$. Noteworthy, a number of these endemics belong to genera known from the eastern slope of the Annamitic range, in Vietnam and in southern China (e.g. Rhodeus laoensis, Microcobitis aff. misgurnoides), which is a distinct zoogeographic unit. Other species are not known from elsewhere in the Mekong drainage but are widely distributed in Vietnam and South China (e.g. Hemibarbus cf. umbrifer). Presently there is no hypothesis explaining this distribution pattern.

Another example of an East Asian species present in the Nam Theun drainage is Misgurnus anguillicaudatus presently known only from near Ban Nape (on Nam Phao upstream of Lak Sao). This species inhabits swamps and rice paddies and can be transported out of water for a long period and it could have been transported by humans across the divide. If the species is not native, the introduction must have happened at least 50 years ago since older persons interviewed in villages commented that the species has always been present. The other 'Vietnamese' species are less likely to have been introduced by humans since they would not survive the transport, they are of no special food interest, and they were found only far up in the tributaries of the Nakai Reservoir, in the Nakai
National Protected Area (NPA), upstream of the last village.

The first survey in 1996 recorded 60 species in the Nam Theun. The following surveys added 14 species. Even the 2012 still added 2 species. This suggests that additional surveys still might add a few species. The number of potential additional species in the upper Nam Theun is probably very low. This is not the case for the lowermost stretch. The two additional species recorded by the 2012 survey were obtained in the lower Nam Theun (Ambastaia nigrolineata, Puntioplites falcifer). It is not clear whether the increase of the number of species in the lower Nam Theun is due to a less intensive sampling because of the more difficult (and expensive) access, or if it is the result of species from the slow flowing waters from near the Theun-Hinboun Reservoir now being able to move upstream because of the very much reduced flow (e.g., Parambassis sp. 'slender'). Exotic species have also appeared in the reservoir and some have the potential to become invasive (e.g. Parambassis siamensis, Cottet et al., same issue).

Although most of the species originally recorded on Nakai Plateau have disappeared after inundation, all have been observed since, upstream or downstream of the reservoir. The single exception is Pangio aff. fusca, which is not conclusive since the species had been collected only in 1996 in crevices, an habitat difficult to sample. The later surveys, before and after construction of the dam did not obtain that species.

Whether all the species endemic to the Nam Theun drainage will be able to maintain over time is still an open 
Table I. Native fish species recorded in the Nam Theun drainage, their general distribution outside Nam Theun, the level of knowledge of their biology, and their biodiversity importance. Biology: $0=$ unknown; $1=$ partly known; 2 = known. Distribution: $a=$ widely distributed in Southeast Asia; $b=$ widely distributed in Mekong drainage; $c$ = widely distributed and/or abundant upstream of the inundation zone or in other tributaries of the Nam Theun; $d$ = range totally or largely in inundation zone and/or in Nam Theun downstream.

Tableau I. Poissons indigènes recensés dans le bassin de la Nam Theun, leur distribution générale en dehors du bassin de la Nam Theun, le degré de connaissance de leur biologie et leur importance en termes de biodiversité. Biologie : $0=$ inconnue ; 1 = partiellement connue ; $2=$ connue. Distribution : $a=$ espèce largement distribuée en Asie du Sud-Est ; $b=$ espèce largement distribuée dans le bassin du Mékong ; $c$ = espèce largement distribuée et/ou abondante en amont de la zone d'inondation ou dans d'autres affluents de la Nam Theun; $d$ = espèce totalement ou en partie présente dans la zone d'inondation et/ou dans la Nam Theun en aval.

\begin{tabular}{|c|c|c|c|c|c|c|c|c|}
\hline & \multirow[t]{2}{*}{ Biology } & \multicolumn{2}{|c|}{\begin{tabular}{|c|} 
Biodiversity \\
importance in context \\
of present report
\end{tabular}} & \multicolumn{4}{|c|}{ Distribution } & \multirow[t]{2}{*}{$\begin{array}{l}\text { General distribution } \\
\text { (raw outline) }\end{array}$} \\
\hline & & important & \begin{tabular}{c|} 
less \\
important
\end{tabular} & $\mathbf{a}$ & $\mathbf{b}$ & c & d & \\
\hline \multicolumn{9}{|l|}{ Anguillidae } \\
\hline Anguilla marmorata (?) & 1 & & $x$ & $\mathrm{x}$ & & & & $\begin{array}{l}\text { Indo-West Pacific; } \\
\text { occasional in Mekong }\end{array}$ \\
\hline \multicolumn{9}{|l|}{ Cyprinidae } \\
\hline $\begin{array}{l}\text { Amblypharyngodon } \\
\text { chulabornae }\end{array}$ & 1 & & $x$ & $x$ & & & & Mainland Southeast Asia \\
\hline Bangana elegans & 0 & $x$ & & & & $x$ & & $\begin{array}{l}\text { Nam Theun - Nam } \\
\text { Gnouang endemic }\end{array}$ \\
\hline Barbodes aurotaeniatus & 0 & & $x$ & & $x$ & & & Mekong drainage \\
\hline Cyclocheilichthys armatus & 1 & & $x$ & $x$ & & & & Southeast Asia \\
\hline Cyclocheilichthys repasson & 1 & & $x$ & $x$ & & & & Southeast Asia \\
\hline Devario fangfangae & 0 & $\mathrm{x}$ & & & & $x$ & & $\begin{array}{l}\text { Nam Theun - Nam } \\
\text { Gnouang endemic }\end{array}$ \\
\hline Esomus metallicus & 1 & & $x$ & $x$ & & & & Mainland Southeast Asia \\
\hline Folifer cf. brevifilis & 0 & & $x$ & $x$ & & & & Southeast and East Asia \\
\hline Garra cambodgiensis & 0 & & $x$ & & $x$ & & & Mainland Southeast Asia \\
\hline Garra cyrano & 0 & & $x$ & & $x$ & & & Middle Mekong drainage \\
\hline Garra theunensis & 0 & & $x$ & & $x$ & & & Middle Mekong drainage \\
\hline Hampala macrolepidota & 1 & & $x$ & $x$ & & & & Southeast Asia \\
\hline Hemibarbus cf. umbrifer & 0 & & $x$ & $x$ & & & & East Asia \\
\hline Hemiculterella macrolepis & 0 & & $x$ & & $x$ & & & Middle Mekong drainage \\
\hline Hypsibarbus vernayi & 1 & & $x$ & & $\mathrm{x}$ & & & Mainland Southeast Asia \\
\hline Luciocyprinus striolatus & 0 & $x$ & & & $\mathrm{x}$ & & & Middle Mekong drainage \\
\hline Mystacoleucus marginatus & 1 & & $x$ & $x$ & & & & Southeast Asia \\
\hline Neolissochilus blanci & 0 & & $x$ & & $x$ & & & Mekong dbasin \\
\hline Onychostoma fusiforme & 0 & & $x$ & & $x$ & & & Middle Mekong drainage \\
\hline Poropuntius carinatus & 0 & & $x$ & & $x$ & & & $\begin{array}{l}\text { Middle Mekong and } \\
\text { Salween drainages }\end{array}$ \\
\hline Puntioplites falcifer & 1 & & $x$ & & $x$ & & & Mekong drainage \\
\hline Puntius brevis & 0 & & $x$ & $\mathrm{x}$ & & & & Southeast Asia \\
\hline
\end{tabular}


Table I. Continued.

Tableau I. Suite.

\begin{tabular}{|c|c|c|c|c|c|c|c|c|}
\hline & \multirow[t]{2}{*}{ Biology } & \multicolumn{2}{|c|}{$\begin{array}{c}\text { Biodiversity } \\
\text { importance in context } \\
\text { of present report }\end{array}$} & \multicolumn{4}{|c|}{ Distribution } & \multirow[t]{2}{*}{$\begin{array}{l}\text { General distribution } \\
\text { (raw outline) }\end{array}$} \\
\hline & & important & \begin{tabular}{|c|} 
less \\
important
\end{tabular} & $\mathbf{a}$ & $\mathbf{b}$ & c & d & \\
\hline Raiamas guttatus & 0 & & $x$ & $x$ & & & & Southeast Asia \\
\hline Rasbora paviana & 0 & & $x$ & $x$ & & & & Mainland Southeast Asia \\
\hline Rhodeus laoensis & 0 & $\mathrm{x}$ & & & & & $\mathrm{x}$ & Nam Theun endemic \\
\hline $\begin{array}{l}\text { Scaphiodonichthys } \\
\text { acanthopterus }\end{array}$ & 0 & & $x$ & & $\mathrm{x}$ & & & $\begin{array}{l}\text { Mekong and Chao Phraya } \\
\text { drainages }\end{array}$ \\
\hline Scaphognathops theunensis & 0 & $x$ & & & & & $\mathrm{x}$ & $\begin{array}{l}\text { Nam Theun - Nam } \\
\text { Gnouang endemic }\end{array}$ \\
\hline Tor ater & 0 & $\mathrm{x}$ & & & & $x$ & & Nam Theun endemic \\
\hline Tor laterivittatus & 0 & & $x$ & & $\mathrm{x}$ & & & Middle Mekong drainage \\
\hline Tor tambra & 0 & & $x$ & & $\mathrm{x}$ & & & Southeast Asia \\
\hline Tor tambroides & 0 & & $x$ & & $\mathrm{x}$ & & & Southeast Asia \\
\hline \multicolumn{9}{|l|}{ Gyrinocheilidae } \\
\hline Gyrinocheilus aymonieri & 1 & & $\mathrm{x}$ & & $\mathrm{x}$ & & & Mainland Southeast Asia \\
\hline \multicolumn{9}{|l|}{ Balitoridae } \\
\hline Balitora lancangjiangensis & 0 & & $x$ & & $\mathrm{x}$ & & & Middle Mekong drainage \\
\hline Balitoropsis yunnanensis & 0 & & $x$ & & $\mathrm{x}$ & & & Mekong basin \\
\hline Hemimyzon papilio & 0 & & $x$ & & $\mathrm{x}$ & & & Middle Mekong drainage \\
\hline Homalopteroides smithi & 0 & & $x$ & $x$ & & & & Mainland Southeast Asia \\
\hline \multicolumn{9}{|l|}{ Nemacheilidae } \\
\hline Nemacheilus arenicolus & 0 & & $x$ & & & $x$ & & Nam Theun endemic \\
\hline Schistura atra & 0 & $x$ & & & & $x$ & & Nam Theun endemic \\
\hline Schistura cataracta & 0 & $x$ & & & & $x$ & & Nam Theun endemic \\
\hline Schistura dorsizona & 0 & & $x$ & & $\mathrm{x}$ & & & Middle Mekong drainage \\
\hline Schistura kongphengi & 0 & & $x$ & & $x$ & & & Middle Mekong drainage \\
\hline Schistura nudidorsum & 0 & & $x$ & & & $\mathrm{x}$ & & Nam Theun endemic \\
\hline Schistura obeini & 0 & $x$ & & & & $x$ & & Nam Theun endemic \\
\hline Schistura sombooni & 0 & & $\mathrm{x}$ & & $x$ & & & Middle Mekong drainage \\
\hline Schistura tubulinaris & 0 & $x$ & & & & $\mathrm{x}$ & & Nam Theun endemic \\
\hline \multicolumn{9}{|l|}{ Cobitidae } \\
\hline Lepidocephalichthys hasselti & 0 & & $x$ & $x$ & & & & Southeast Asia \\
\hline $\begin{array}{l}\text { Microcobitis aff. } \\
\text { misgurnoides }\end{array}$ & 0 & $x$ & & & & & $x$ & $\begin{array}{l}\text { Nam Theun-Nam } \\
\text { Gnouang endemic }\end{array}$ \\
\hline Misgurnus anguillicaudatus & 2 & & $\mathrm{x}$ & $\mathrm{x}$ & & & & East Asia \\
\hline Pangio aff. fusca & 0 & $x$ & & & & & $\mathrm{x}$ & Nam Theun endemic \\
\hline \multicolumn{9}{|l|}{ Botiidae } \\
\hline Ambastaia nigrolineata & 0 & & $x$ & & $\mathrm{x}$ & & & $\begin{array}{l}\text { Mekong and Chao Phraya } \\
\text { basins }\end{array}$ \\
\hline \multicolumn{9}{|l|}{\begin{tabular}{|l} 
Bagridae \\
\end{tabular}} \\
\hline Hemibagrus wyckioides & 1 & & $x$ & & $\mathrm{x}$ & & & Mekong drainage \\
\hline Pseudomystus siamensis & 0 & & $x$ & $x$ & & & & Mainland Southeast Asia \\
\hline
\end{tabular}


Table I. Continued.

Tableau I. Suite.

\begin{tabular}{|c|c|c|c|c|c|c|c|c|}
\hline & \multirow[t]{2}{*}{ Biology } & \multicolumn{2}{|c|}{$\begin{array}{c}\text { Biodiversity } \\
\text { importance in context } \\
\text { of present report }\end{array}$} & \multicolumn{4}{|c|}{ Distribution } & \multirow[t]{2}{*}{$\begin{array}{l}\text { General distribution } \\
\text { (raw outline) }\end{array}$} \\
\hline & & important & \begin{tabular}{|c|} 
less \\
important
\end{tabular} & a & b & c & $\mathbf{d}$ & \\
\hline \multicolumn{9}{|l|}{ Siluridae } \\
\hline Pterocryptis inusitata & 0 & $x$ & & & & $x$ & & Nam Theun endemic \\
\hline \multicolumn{9}{|l|}{ Clariidae } \\
\hline Clarias cf. batrachus & 3 & & $x$ & $x$ & & & & Southeast Asia \\
\hline \multicolumn{9}{|l|}{ Sisoridae } \\
\hline Bagarius yarrelli & 1 & & $x$ & $x$ & & & & Southeast and South Asia \\
\hline Glyptothorax horai & 0 & & $x$ & & $x$ & & & Middle Mekong drainage \\
\hline Glyptothorax laosensis & 0 & & $x$ & $x$ & & & & $\begin{array}{l}\text { Mekong and Chao Phraya } \\
\text { drainages }\end{array}$ \\
\hline Glyptothorax aff. zanaensis & 0 & & $x$ & & $x$ & & & Middle Mekong drainages \\
\hline Oreoglanis hypsiurus & 0 & $x$ & & & & $x$ & & Nam Theun endemic \\
\hline Oreoglanis lepturus & 0 & $x$ & & & & $x$ & & Nam Theun endemic \\
\hline Pseudechenei sympelvica & 0 & & $x$ & & $x$ & & & Mekong basin \\
\hline \multicolumn{9}{|l|}{ Adrianichthyidae } \\
\hline Oryzias pectoralis & 0 & $x$ & & & & & $x$ & Nam Theun endemic \\
\hline Oryzias sp. 'river' & 0 & $\mathrm{x}$ & & & & & $\mathrm{x}$ & Nam Theun endemic \\
\hline Oryzias sp. 'swamp' & 1 & $x$ & & & & & $\mathrm{x}$ & Nam Theun endemic \\
\hline \multicolumn{9}{|l|}{ Synbranchidae } \\
\hline Monopterus javanensis & 2 & & $x$ & $x$ & & & & Southeast and East Asia \\
\hline \multicolumn{9}{|l|}{ Ambassidae } \\
\hline Parambassis sp. 'slender' & 0 & $x ?$ & & & & & $\mathrm{x}$ & Nam Theun endemic? \\
\hline \multicolumn{9}{|l|}{ Odontobutidae } \\
\hline Neodontobutis aurarmus & 0 & & $x$ & & $x$ & & & Mekong basin \\
\hline \multicolumn{9}{|l|}{ Gobiidae } \\
\hline Papuligobius ocellatus & 0 & & $x$ & & $x$ & & & Mekong basin \\
\hline Rhinogobius lineatus & 0 & $x$ & & & & & $x$ & Nam Theun endemic \\
\hline \multicolumn{9}{|l|}{ Anabantidae } \\
\hline Anabas testudineus & 2 & & $x$ & $x$ & & & & Southeast and South Asia \\
\hline \multicolumn{9}{|l|}{ Osphronemidae } \\
\hline Trichopsis schalleri & 1 & $?$ & & $x$ & & & & Mekong basin \\
\hline \multicolumn{9}{|l|}{ Channidae } \\
\hline Channa gachua & 1 & & $x$ & $x$ & & & & Southeast Asia \\
\hline Channa striata & 2 & & $x$ & $x$ & & & & Southeast and South Asia \\
\hline \multicolumn{9}{|l|}{ Mastacembelidae } \\
\hline Mastacembelus armatus & 0 & & $x$ & $x$ & & & & Southeast and South Asia \\
\hline
\end{tabular}


Table II. Fish species endemic to the Xe Bangfai drainage and their biodiversity importance. $\mathrm{a}=$ range totally or mainly in NTPC area; $b=$ range exclusively or mainly upstream of NTPC activities.

Tableau II. Espèces de poissons endémiques au bassin de la Xe Bangfai et leur importance en termes de biodiversité. $a=$ espèce totalement ou principalement présente dans la zone de NTPC ; $\mathrm{b}=$ espèce présente exclusivement ou principalement en amont des activités de NTPC.

\begin{tabular}{|c|c|c|c|c|c|}
\hline & \multicolumn{2}{|c|}{$\begin{array}{c}\text { Biodiversity } \\
\text { importance in } \\
\text { context of present } \\
\text { report }\end{array}$} & \multicolumn{2}{|c|}{ Distribution } & \\
\hline & important & \begin{tabular}{|c|} 
less \\
important
\end{tabular} & a & b & \\
\hline \multicolumn{6}{|l|}{ Cyprinidae } \\
\hline Bangana musaei * & & $x$ & & $x$ & $\begin{array}{l}\text { cave species found in Xe } \\
\text { Bangfai tunnel }\end{array}$ \\
\hline Devario sp. 'green' & $x$ & & $x$ & & Nam Kathang Gnai \\
\hline Devario cf. quangbinhensis & & $? \mathrm{x}$ & & $? \mathrm{x}$ & Nam Oula \\
\hline \multicolumn{6}{|l|}{ Nemacheilidae } \\
\hline Schistura punctifasciata & & $x$ & & $x$ & \\
\hline Schistura sp. 'Nam Kathang' & $x$ & & $x$ & & Nam Kathang Gnai \\
\hline \multicolumn{6}{|l|}{ Cobitidae } \\
\hline Acantopsis sp. 'dwarf males' & $? \mathrm{x}$ & & $? \mathrm{x}$ & & Lower Xe Bangfai \\
\hline Acantopsis sp. 'vertical spots' & $? \mathrm{x}$ & & $? \mathrm{x}$ & & Nam Oula \\
\hline \multicolumn{6}{|l|}{ Sisoridae } \\
\hline Glyptothorax aff. fuscus 2 & & $x$ & & $\mathrm{x}$ & Xe Noy \\
\hline \multicolumn{6}{|l|}{ Odontobutidae } \\
\hline Terateleotris aspro & & $x$ & & $x$ & Upper Xe Bangfai \\
\hline
\end{tabular}

* Bangana musaei is a biodiversity very important species with an extremely small range in the cave system of the underground course of the Xe Bangfai. It is however totally outside the impact zone of NTPC activities.

question. Most concerned species are Scaphognathops theunensis, Oryzias sp. 'swamp', and Rhodeus laoensis. Luciocyprinus striolatus, a rare and globally endangered species, is also of special concern.

\subsection{Xe Bangfai drainage}

178 species have been recorded in the Xe Bangfai drainage (Appendix 1). The fauna of the Xe Bangfai is similar to that reported for the other main tributaries of the Mekong in Laos, from the
Xe Kong in the South until the Nam Ngum in the North, at least in the floodplain. Those of these rivers that have been studied tend to have distinctive fauna in the upper stretches. A single site could be efficiently sampled in the upper stretch of the Xe Bangfai (upstream of its underground course). Only 9 species are apparently endemic to the Xe Bangfai (Tab. II). Only one of the species very similar to or possibly shared with Vietnam (Devario aff. quangbinhensis) is of biodiversity importance (small distribution range). 
The Xe Bangfai drainage has a typical Mekong floodplain fish fauna. A number of these Mekong species have not yet been recorded in the Xe Bangfai but are expected to be present. The 2012 survey included habitats that had not been sampled before (because they were not directly impacted by the Nam Theun 2 operations). Four days of sampling ( 7 sites) yielded 29 additional species. Most were from tributaries and swamps. Four of these additional species are presently known only from the Xe Bangfai; some will certainly be discovered in adjacent drainages but others are potentially endemic and biodiversity important (Tab. II). Five of the Xe Bangfai endemics have their known range entirely or partly upstream of the area directly impacted by Nam Theun 2 activities.

\subsection{Cave fishes}

The Xe Bangfai crosses several extensive karst massives. Several fish species have been observed in caves. These are mostly individuals of surface species showing no sign of adaptation to underground life. The exception is Bangana musaei that has been observed only in caves around the upstream entrance of the underground stretch of the Xe Bangfai, far upstream of the area impacted by Nam Theun 2 activities (Kottelat \& Steiner, 2011). Another cave fish (Troglocyclocheilus khammouanensis) is known from the resurgence of the Nam Done from the karst massive between the Nam Done (a tributary of the Mekong) and Xe Bangfai drainages (on the road between Thakek and Mahaxai) (Kottelat \& Bréhier, 1999). Although the outlet is in the Nam Done catchment, considering the morphology and functioning of karst systems, the actual range of the species may extend for a long distance and the species could potentially be impacted by the project, especially by surface pollution and lowering of the water table.

\section{BIODIVERSITY IMPORTANT SPECIES}

\subsection{Rationale for focusing on biodiversity important species}

In the context of the impact of a project on aquatic biodiversity, some species have a greater biodiversity importance than others, either because: - their range is totally or largely impacted by the project; or a part of their range vital at a period of their life-history cycle is totally or largely impacted by the project (for example an obligatory and unique breeding site);

- although they may have a large range they are rare throughout this range, their populations are declining quickly (or under a threat of sharp decline), or they are protected or listed as endangered by local, national or international legal instruments (species that cannot be fished; species whose trade is forbidden or limited [e.g. CITES], etc.); - they have special evolutionary, scientific, emotional, or cultural importance (e.g. freshwater dolphin, giant Mekong catfish).

\subsection{Biodiversity important species in Nam Theun 2 project area}

Most of the endemic species found in the Nam Theun 2 project area have 
narrow ecological requirements. Most of them are specialised for habitats in fast water and they are found exclusively in these habitats. On Nakai Plateau, before inundation, most of these fast-water species were restricted to former rapids or were present only at a few specific sites. In the inundated zone, the species requiring rapids and fast water are now absent or have populations with fewer individuals. As their range upstream of the reservoir is not inundated, a part of their habitat remains and is protected by the NPA. In repeated interviews in 1996, 2001, 2003 and 2007, villagers constantly answered that no species was known to be migrating or to have earlier migrated between the plateau and the upstream Nam Theun and Nam Xot or to use the plateau as exclusive spawning and nursery ground. However, they become indirectly impacted, for example by increasing human population or human activity in the NPA (e.g. the introduction of exotics and their pathogens).

The species impacted by the inundation only in part of their range and with strong populations upstream of the reservoir are classified as of lesser biodiversity importance and do not seem of priority concern (Tab. I).

Some species endemic to the Nam Theun, Nam Gnouang and Xe Bangfai drainages occur in habitats or areas where their survival does not seem to be an issue after impoundment (suggested by post-inundation surveys). These species are mainly small benthic fishes. They are Schistura atra, Schistura obeini, Schistura tubulinaris, Schistura cataracta, Schistura nudidorsum, Nemacheilus arenicolus, Pterocryptis inusitata and Oreoglanis hypsiurus.

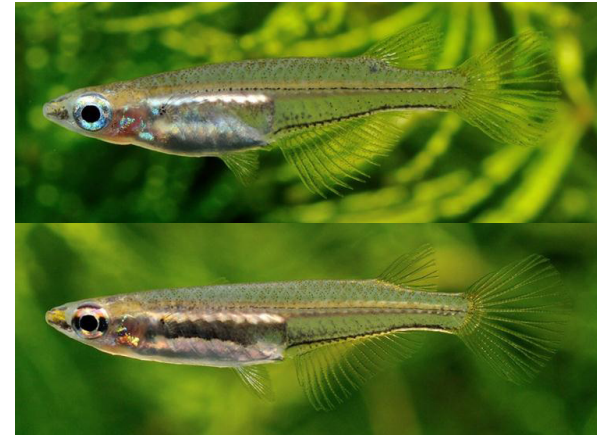

Fig. 2. Oryzias sp. 'swamp', male (above) and female (below); about $15 \mathrm{~mm} \mathrm{SL} \mathrm{(photograph} \odot$ by Hiromichi Nemoto).

Fig. 2. Oryzias sp. 'swamp', mâle (haut) et femelle (bas) ; environ $15 \mathrm{~mm}$ LS (photographie (c) par Hiromichi Nemoto).

The survival of some midwater species is also considered not to be an issue such as Devario fangfangae, Parambassis sp. 'slender' (suspected new species) and Oryzias pectoralis.

The present paper focuses on biodiversity important species.

\subsubsection{Oryzias sp. 'swamp'}

Oryzias sp. 'swamp' (Fig. 2) is not yet named following the rules of the International Code of Zoological Nomenclature and the name Oryzias sp. 'swamp' is used awaiting the publication of the formal description and the 'official' name. It is known only from the Nakai Plateau and its known distribution range is almost totally inundated by Nakai Reservoir.

The species was present in the samples collected as early as 1996 but was not recognised. It was mixed with Oryzias sp. 'river', which then was misidentified as Oryzias sinensis. Oryzias sp. 'swamp' is distinguished from 
Oryzias sp. 'river' by morphological characters (especially in head shape, pigments on the head, maximum size, number of anal-fin rays). Molecular data unambiguously show that it is distinct from Oryzias sp. 'river' and that both are distinct from all known Oryzias species.

Oryzias sp. 'swamp' is the smallest fish (and vertebrate) species known on the plateau. The largest size observed is $20 \mathrm{~mm} \mathrm{SL}$ although most specimens are below $18 \mathrm{~mm} \mathrm{SL}$.

Before inundation, Oryzias sp. 'swamp' was observed in the dry season in most pools, ponds and swamps on the Nakai Plateau (Kottelat, 2007), where it was often present in large numbers. It survives the dry season in shallow pools, with high temperature, low or no dissolved oxygen, and high organic pollution as these pools are usually used by water buffaloes. The fish lives immediately under the water surface, and its upturned mouth allows it to breath in the very thin upper layer of water in contact with air.

However, these extreme habitats were erroneously interpreted as specialised habitat of the species. In fact the sites where it was most abundant had cooler water, with submerged vegetation. In these habitats, the males are 'colourful' with conspicuous red bands along the lower and upper edges of the caudal fin. These sexually dimorphic colour marks are totally indistinct in murky water.

Little is known on the biology of the species. Some aquarium observations indicate that individuals of about 12$16 \mathrm{~mm}$ SL spawn 1 or 2 eggs per day during the warm-wet season (JuneSeptember 2012). It seems that in early September, the oldest individuals of the offsprings had already started to spawn, which corresponds to about 3 months. At hatching, the fry is about 4 $\mathrm{mm}$, which is smaller than known in all other species of the genus (K. Kubota, pers. comm., 2012). Finally, these observations suggest that Oryzias sp. 'swamp' deposits the eggs on the substrate or in crevices while in the other species of Oryzias the female carries a cluster of eggs for a few days hanging near the genital opening.

Search for Oryzias sp. 'swamp' in 2009 and 2011 along the shores of the Nakai Reservoir and in adjacent swamps and wetlands failed to find the species and it became of serious concern. The species was 'rediscovered' in 2012 at a single site. Investigations were conducted in the dry season 2013 by the Water Quality and Biodiversity department of the Nam Theun 2 Power Company along the shores of the reservoir. This survey included 68 swamps and recorded the presence of Oryzias sp. 'swamp' at 8 sites. Most of the swamps where the species was observed are located below full supply level of the reservoir (NTPC unpublished data; M. Cottet, pers. comm., 2014).

\subsubsection{Oryzias sp. 'river'}

Oryzias sp. 'river' (Fig. 3) too is not yet formally named and is temporarily called Oryzias sp. 'river'. It is known only from the Nakai Plateau and its whole known distribution range is inundated by Nakai Reservoir. It was misidentified as Oryzias sinensis in the earlier surveys. Before inundation, at the end of the dry season the species was collected only in the Nam Theun River, in low numbers, in backwaters or 


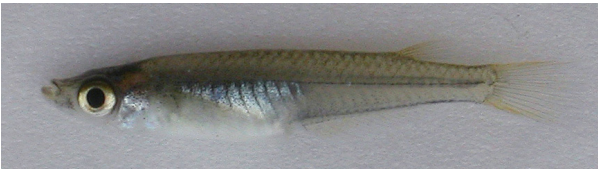

Fig. 3. Oryzias sp. 'river', adult female.

Fig. 3. Oryzias sp. 'river', femelle adulte.

among shore vegetation. It seems that with the onset of the rainy season this species moved to the flooded areas where it spawned. Other Oryzias species of similar size reach sexual maturity in about 10-12 weeks, and several generations may succeed in a single annual cycle as observed in its relative Oryzias sp. 'swamp'. When the water level decreases it survives in pools and in the river. However, it seems that most individuals do not survive in pools when the water level becomes too low, possibly because of high temperature and low water quality.

In 2012, the species was present in abundance all around the reservoir and in backwaters and immediately below of the Nakai Dam. The species has apparently adapted very well to reservoir conditions and does not require any management measure.

\subsubsection{Scaphognathops theunensis}

Scaphognathops theunensis (Fig. 4) is endemic to the Nam Theun and Nam Gnouang main rivers. In the Nam Theun its range is totally included in the area impacted by the Nam Theun 2 project. In 2002 a survey was conducted in the Nam Gnouang to check its presence, distribution and habitat preferences (Kottelat, 2002). Since, the known distribution in the Nam Gnouang is totally included in the area impacted by the

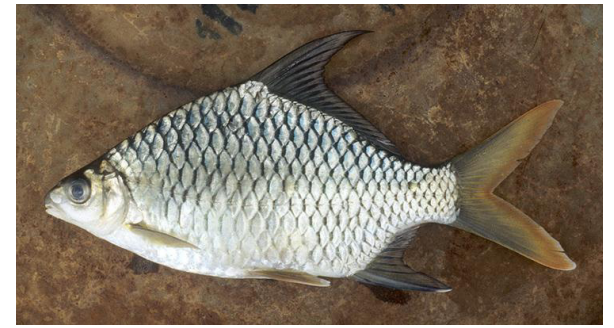

Fig. 4. Scaphognathops theunensis, adult, $160 \mathrm{~mm} \mathrm{SL}$, collected in 1996 in Ban Thalang. Fig. 4. Scaphognathops theunensis, adulte, 160 mm LS, collecté en 1996 à Ban Thalang.

Theun-Hinboun Reservoir and its extension reservoir. Information gathered in 2007 and 2009 indicated that the species is present in the lowermost Nam Phao, a tributary of the Nam Theun River entering it downstream of the Nakai Dam. Scaphognathops theunensis could not be found downstream of the confluence of the Nam Theun and Nam Gnouang (downstream known as Nam Kading). Research conducted in 2002 showed that it is replaced by Scaphognathops bandanensis in the Nam Mouang, a tributary of the Nam Kading.

The species lives in deep pools, usually immediately below riffles and rapids. Small juveniles had been collected in fast water at the future Nakai Dam site in 1996. Apparently it feeds by scrapping algae growing on stones and logs, and the micro-invertebrates living among the algae, with the narrow lower jaw terminated by a cornified sheath.

Because of its habitat requirements and feeding habits, it was expected that Scaphognathops theunensis would not survive in both the reservoir condition (Nakai Reservoir and Nam Gnouang 
Reservoir) and in the lower Nam Theun because of low post-inundation flow. With the 2002 survey's condition, it was considered that it would survive only in the Nam Gnouang, if that river remained ecologically and hydrologically intact. Since that time, with the construction of the Theun-Hinboun extension on the Nam Gnouang, the survival chances of Scaphognathops theunensis are very low in this area as well.

The presence of the species in the lower Nam Phao was suggested by interviews with local villagers in 2007 and 2009. With the poor habitat quality in the Nam Phao downstream of Laksao and the very poor condition of its tributary Nam Kata (i.e. low flow, warm water, eutrophication, and severe local mining pollution), a potential population in the Nam Phao cannot be considered safe and requires management measures to ensure its survival.

In 2012, three individuals, about $100 \mathrm{~mm} \mathrm{SL}$, were observed in the catch of fishermen in the Nam Theun downstream area. This observation confirmed the presence of the species and their size suggests that these indivuals were about 2-3 years old, which implies that they were born in 20092010 , that is after completion of Nakai Dam. This leads to suggest that the species had been able to survive (at least temporarily) the low flow conditions. However, the parents were born probably 3-4 years before, which was before completion of Nakai Dam. Future will show whether the individuals born after closure of the dam will be able to reach maturity and spawn.

Villagers in the Nam Theun downstream of the Nakai dam reported that the species was present in the lower

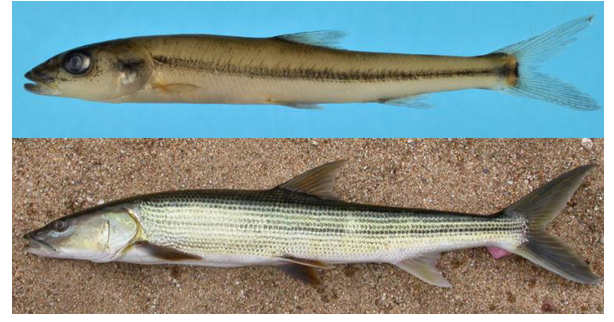

Fig. 5. Luciocyprinus striolatus; juvenile, $61 \mathrm{~mm}$ SL (above) and subadult about $400 \mathrm{~mm} \mathrm{SL}$ (below).

Fig. 5. Luciocyprinus striolatus ; juvénile, $61 \mathrm{~mm}$ LS (haut) et subadulte, environ $400 \mathrm{~mm}$ LS (bas).

Nam Phao but not abundant, and was also present in the Nam Theun upstream of the confluence with the Nam Phao. They considered the species now as 'not common'. Finally, individuals' size was reported to be smaller than before construction of Nakai Dam.

\subsubsection{Luciocyprinus striolatus}

Luciocyprinus striolatus (Fig. 5) is known from the Nam Theun and Nam Gnouang drainages. Other populations are known in the upper Xe Kong, Nam Ngiep and $\mathrm{Nam} \mathrm{Ou}$ in Laos, and in Xishuangbanna in Yunnan (China). In all these areas it is rarely observed and the only rivers where it has been regularly seen are the Nam Gnouang and upper Nam Theun. It is not present in the Mekong main river or in the lower parts of its main tributaries. As most of the upper parts of the other main tributaries of the Mekong in Laos have not yet been surveyed (or the results have not been made public), its presence in some additional drainages cannot be excluded. In any case its range is very fragmented. 
Also, it cannot yet be excluded that some of these isolated populations in fact are different species.

Luciocyprinus striolatus inhabits large deep pools. Its habitat on the Nakai Plateau has been lost by inundation and it is unlikely to maintain a significant population in the Nam Theun downstream of Nakai Dam. Its only known intact habitats are the small stretches of the Nam Xot and upper Nam Theun. If the species does not migrate and does not need to travel long distance to feed, it will apparently survive in the deep pools above FSL.

Because it is a very large fish (up to at least $1.5 \mathrm{~m}$, with villagers mentioning sizes above $2 \mathrm{~m}$ ), the number of individuals is predictably very low and overfishing is an immediate threat. It is most likely already overfished, even if not the object of a specific fishing activity. In recent years, it also attracted attention as a target for sport fishing. Villagers from both above the reservoir and downstream of Nakai Dam interviewed during the surveys 1996, 2001 and 2003 surveys all commented that the species is not migratory and spawns in January-February in rapids (Kottelat, 1996, 2002).

In 2012, L. striolatus was observed in the Nam Theun both upstream and downstream of the Nakai Reservoir. It is not known in the Nam Phao. In the upstream Nam Theun, four individuals about 50-60 mm SL were observed at the uppermost extremity of a pool, immediately downstream of the rapids/ riffles. Villagers reported that they are no longer observing large individuals and that those they now collect are not more than $30 \mathrm{~cm}$ long. They consider

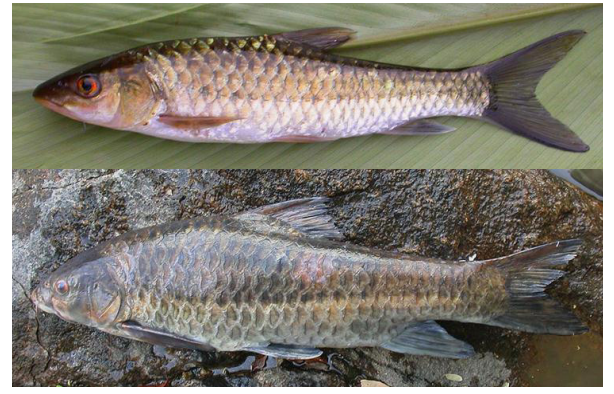

Fig. 6. Tor ater, juvenile, $180 \mathrm{~mm} \mathrm{SL} \mathrm{(above)}$ and adult, $460 \mathrm{~mm} \mathrm{SL}$ (below).

Fig. 6. Tor ater; juvénile, $180 \mathrm{~mm}$ LS (haut) et adulte, $460 \mathrm{~mm}$ LS (bas).

that overfishing is responsible for the absence of larger individuals.

\subsubsection{Tor ater}

Tor ater (Fig. 6) is definitively recorded only from the Nam Xot and Nam Theun upstream of Nakai reservoir. Although originally described (Roberts, 1999) on the basis of specimens obtained from villagers in Ban Thalang there is no indication of its earlier presence on Nakai Plateau. A survey conducted in 2002 in the Nam Gnouang and Xe Bangfai drainages to investigate its possible presence outside the Nam Theun drainage failed to find it (Kottelat, 2002). Its distribution and biology in the Nam Theun drainage was investigated in 2003 (Kottelat, 2004). Villagers do not report having seen the species on the plateau and as far as known it completes it whole life cycle upstream of the plateau, as suggested by the presence of individuals of three age classes.

Adult Tor ater seem to inhabit deep pools and to spawn in riffles. 


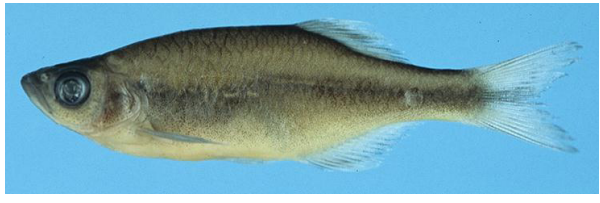

Fig. 7. Devario sp. 'green', $47 \mathrm{~mm} \mathrm{SL}$.

Fig. 7. Devario sp. 'green', 47 mm LS.

The smallest known individuals 104$140 \mathrm{~mm}$ SL had been obtained in a small creek.

The species was not observed by the 2012 survey and no information were obtained. The site where juveniles had been obtained in 2003 was visited in 2012 but a small village has been established and sampling was not possible at this exact site.

The only information available on this species were obtained by the 2003 survey (Kottelat, 2004) and are very limited. Study is needed to determine its distribution, ecological requirements, reproduction pattern, and population size.

\subsubsection{Devario sp. 'green'}

This species (Fig. 7) had been collected only in the Nam Kathang Gnai, a branch of the Nam Kathang on Nakai Plateau during the 2007 and 2012 surveys. It is new to science and presently known only from this stream. The species is not affected by the inundation of the reservoir since this stream flows directly to the Xe Bangfai, not to the Nam Theun. However, some resettled villages are located on and across the divide between the Nam Theun and Nam Kathang Gnai, and other villages are very close to the divide. Then, the main expected disturbance of its habitat may be related to the disturbance by villages (e.g. agricultural activities).
Species of the genus Devario often have a large range and are frequent within their range. For example, Devario fangfangae, which is endemic to the Nam Theun and Nam Gnouang drainages, is mainly a species of forest streams, but it is also regularly seen in other habitats, and has also been observed in the reservoir. Other species, on the reverse, may have very restricted ranges. Devario sp. 'green' was collected in a forest stream habitat, with little water, and probably has the same ecological requirements. It was expected that the species would be present elsewhere in the Nam Kathang or in the Xe Bangfai drainages. The baseline survey conducted in 1996 and 2006 did not show its presence in the $X e$ Bangfai drainage, but the focus then was on the Xe Bangfai main river. Habitats similar to the upper Nam Kathang Gnai were not sampled at that time because none could be accessed.

Attempts to find Devario sp. 'green' outside the Nam Theun 2 project area failed. The only other Devario species observed in the Xe Bangfai drainage during the surveys was in the Nam Oula catchment; it is a conspicuously distinct species, possibly new to science. Adjacent areas in Vietnam are inhabited by Devario quangbinhensis, a species somewhat similar to the Nam Oula one. Anyway, the endemism of Devario sp. 'green' to Nam Theun 2 project area should be confirmed by search for possible additional populations outside the Nakai Plateau. The presence of a second species of the genus in the Nam Oula suggests that the distribution of Devario sp. 'green' might not be very wide since there is no known instance in Southeast Asia of 


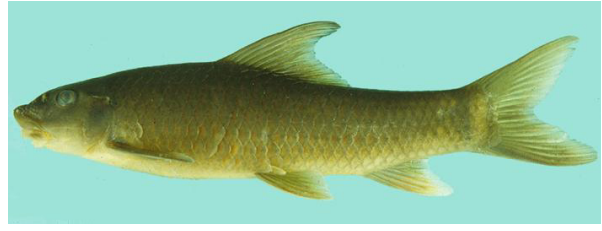

Fig. 8. Bangana elegans: juvenile, $133 \mathrm{~mm} \mathrm{SL}$. Fig. 8. Bangana elegans : juvénile, $133 \mathrm{~mm}$ LS.

two species of Devario occurring together. Alternatively, this might suggest that the two species have different ecological niches.

If Devario sp. 'green' were to turn out to be restricted to Nakai Plateau, then management measures should include e.g. forest cover conservation along the stream, prohibit water abstraction to ensure a constant flow, even low, during the dry season.

\subsubsection{Bangana elegans}

Bangana elegans (Fig. 8) is presently known only from the Nam Kading drainage (Nam Theun and Nam Gnouang Rivers). An earlier tentative record from Nam Ngum was based on a juvenile that could not be identified with accuracy (Kottelat, 2001). Adult Bangana recently collected in the Nam Ngum and Nam Ngiep have been identified as Bangana lippa. There is no data available for intermediate areas. The presence of a Bangana species is expected in headwaters of most rivers north of the Nam Gnouang. Bangana elegans could be present in the drainages immediately north of the Nam Gnouang, at least in the Nam Kading drainage. There is no record of Bangana species south of the Nam Theun drainage.
Bangana elegans inhabits rapids and fast flowing waters, and spawns at rapids. It disappeared from the Nakai Plateau after inundation of the reservoir. It is expected to become rare or disappear in the downstream Nam Theun. It has been observed in the Upper Nam Theun, the Nam Xot, and Nam Noy and individuals from about 2 to $30 \mathrm{~cm}$ had been observed, in the earlier surveys, suggesting that it completes it whole life cycle in these stretches of the rivers. In 1996 villagers in Ban Thalang reported that Bangana elegans undertakes small local migrations to spawn in rapids in November, while people at Nakai Dam site reported its presence year round. It spawns on shallow rocks (reportedly less than $10 \mathrm{~cm}$ deep). Spawning in shallow water means that the eggs and early larvae would not survive a decrease of water level during the few days between spawning and the time the larvae can move away. The time needed is not known but can be expected to be 1-2 weeks. Further, villagers used to catch this species with trident in the rapids during spawning. With less water and shallower rapids, this fish becomes an easier target. Since impoundment of the Nakai Reservoir, the species has never been seen in the inundation zone, except in the parts of Nam Noy (M. Cottet, pers. comm., 2014), Nam Theun and Nam Xot, where these rivers are under FSL.

\subsubsection{Rhodeus laoensis}

Rhodeus laoensis (Fig. 9) is endemic to the Nam Theun and Nam Gnouang drainages. In the Nam Theun, before 


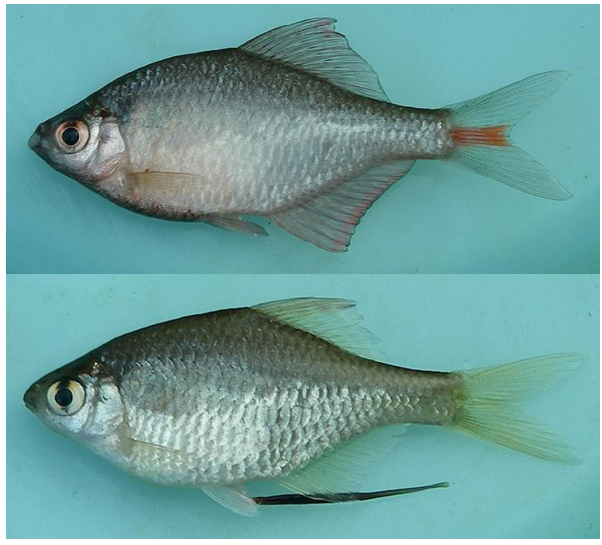

Fig. 9. Rhodeus laoensis; male, about $40 \mathrm{~mm}$ SL (above) and female, about $40 \mathrm{~mm} \mathrm{SL}$ with black ovipositor tube (below).

Fig. 9. Rhodeus laoensis; mâle, d'environ $40 \mathrm{~mm}$ LS (haut) et femelle, d'environ $40 \mathrm{~mm}$ LS avec un tube ovipositeur noir (bas).

inundation it had been observed mainly on the Nakai Plateau and in small tributaries of the Nam Theun upstream. On the plateau (inundation zone) it was found only in the main river and in forest streams and has never been observed in the swamps. This species was extremely frequent, and during the 2001, 2006 and 2007 surveys very small juveniles were abundant. It prefers sections of forest streams with slow or standing water with submerged vegetation and soft bottom, often close to deeper water. If the habitat becomes disturbed by human activity and the current becomes slower and the water slightly turbid, it replaces the typical species of this habitat (especially Devario fangfangae and Rasbora paviana), which become less abundant. This species was also observed downstream of the Nakai Dam area in the Nam Phao in 2007.
Rhodeus laoensis is a bitterling, a group of fishes that spawn their eggs in mussels, where they hatch and remain for 1 to 8 months. The length of the stay in the mussel depends on the bitterling species. There is no data for Rhodeus laoensis but the small size of the freeswimming juveniles suggests it is among the species spending only a short time in the mussel. Bitterlings cannot complete their life cycle without the mussel and their survival is therefore absolutely dependant of the presence of the mussel. Each species of bitterling needs the presence of one (or a few) precise species of mussel (e.g. Liu et al., 2006; Kitamura, 2007), and if that species is not present it will not use other species. While the fish may move for some distance if habitat conditions become unfavourable, the adult mussel cannot move. If the stream bed becomes exposed, polluted, silted or anoxic the mussel dies and this may lead to the local extirpation of the fish.

The mussel has a larval stage, called glochidia. The larvae are parasitic and attach to the gills and fins of fishes until they metamorphose, then they drop to the bottom. This means that the mussel has the potential to be carried by fishes in new habitats or to be carried back to habitats from which they had been extirpated. As they need to be permanently in water, of course they would be unable to establish in the drawdown zone. The time needed for metamorphosis varies depending on species, and there is no data for the mussel of the Nam Theun drainage. Depending on the species, glochidia may need one or a few precise fish species to attach, or may be more generalistic and attach to many different 


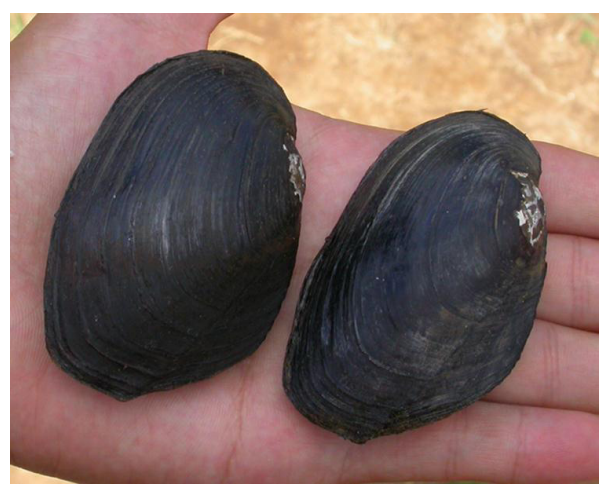

Fig. 10. Pseudodon vondembuschianus, the only species of mussel observed in Nam Theun drainage, in which Rhodeus laoensis probably deposits its eggs.

Fig. 10. Pseudodon vondembuschianus, la seule espèce de moule observée dans le bassin de la Nam Theun, dans laquelle Rhodeus laoensis dépose probablement ses œufs.

fish species. If the glochidia need to attach to a precise fish host (other than the bitterling), then the survival of both the mussel and the bitterling depend of the survival of this host.

The mussel host Rhodeus laoensis is not yet objectively known, but a single species has been collected in the Nam Theun drainage. It belongs to the family Unionidae, as all species used by bitterlings. It has been identified as Pseudodon vondembuschianus (Fig. 10, identification by A. Bogan). The population from Laos had been identified by Brandt (1974) as a subspecies P. V. tumidus. The distribution of Pseudodon vondembuschianus includes mainland Southeast Asia, Sumatra, Java and Borneo. Some authors consider that populations from the Mekong drainage in Laos and Cambodia are a species distinct from those from Indonesia, but this is still debated.
Rhodeus laoensis had not been observed in the inundation zone after 2007. After the impoundment, specimens were observed from villagers in the Nam Theun downstream of the Nakai Dam (M. Cottet, pers. comm., 2014). It has been observed in 2012 in the Nam Theun upstream of the reservoir.

In the Nam Theun drainage, the mussel Pseudodon vondembuschianus was observed in 2009 and 2012 in the Nam Phiat, a small tributary of the Nam Phao. The presence of live mussels in a habitat should not be taken as meaning that the mussel is safe. Many species of Unionidae can live very old (one species up to 120 years) and some species still have surviving individuals but they are functionally extinct because they only subsist as a few localised populations made only of old individuals no longer reproducing, or the number of individuals is too low to support a viable population (Bogan, 1993). A bitterling depending of a functionally extinct species of mussel would be condemned to extinction unless an alternative host can be found. A number of species of mussels have disappeared following the construction of dams in North America (Bogan, 1993, 2006; Watters, 2000).

Many species of bitterlings successfully breed in captivity (Akai et al., 2005) and the conservation program of at least one species in Korea is based on captive breeding. Captive breeding has always been in presence of the mussel.

Pseudodon vondembuschianus or a very similar species of mussel was collected in the Ban Done drainage, where it was common. The identity of this sample has not yet been confirmed. The 


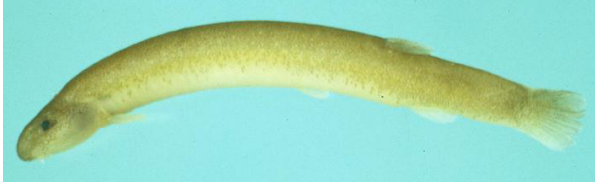

Fig. 11. Pangio aff. fusca, $33 \mathrm{~mm} \mathrm{SL}$. Fig. 11. Pangio aff. fusca, $33 \mathrm{~mm}$ LS.

presence of a population of this species near Nakai Plateau is important as it might be a source of material usable for captive breeding of Rhodeus laoensis or for research. Other species of mussels were also collected in the $\mathrm{Xe}$ Bangfai drainage.

Because the presence of the mussel is necessary to allow the complete life cycle of Rhodeus laoensis, management measures should focus on both the fish and the mussel (Kottelat, 2012b). It is necessary to confirm that Pseudodon vondembuschianus is the species used by Rhodeus laoensis and that Rhodeus laoensis is the species used by the glochidia of this mussel. Should there be more than one species of mussel, there would be the risk of targeting conservation measures at the wrong species. This requires either direct observation of spawning or searching for eggs or fish larvae in the mussels. It is also necessary to establish which fish species is/are used by the glochidia (the larvae of the mussel).

\subsubsection{Pangio aff. fusca}

Pangio aff. fusca (Fig. 11) was earlier identified as Pangio fusca, a species then believed to be widely distributed from the Salween to the Mekong drainages. Later studies have shown that Pangio fusca is actually restricted

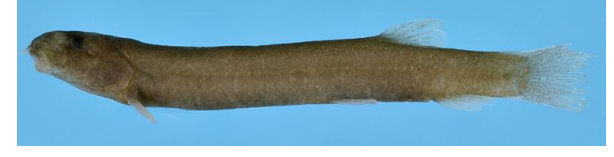

Fig. 12. The second species of Pangio aff. fusca, from the Xe Bangfai drainage.

Fig. 12. La seconde espèce de Pangio aff. fusca, du bassin de la Xe Bangfai.

to the Salween drainage and Tenasserim (Myanmar) and that the populations from the Mekong drainage belong to other species (Britz \& Maclaine, 2007; Britz \& Kottelat, 2010). Further, in earlier reports (Kottelat, 2006, 2007), all the Pangio fusca-like fishes of the Mekong drainage were believed to be a single species, although there was a suspicion that more than one species were confused under this name (Kottelat, 2007). This is now confirmed by a recent and still unpublished study that distinguishes three species, diagnosed by morphological as well as molecular characters. One of them is known only from the Nam Theun drainage (called here Pangio aff. fusca). Another similar species has been observed in the $\mathrm{Xe}$ Bangfai by the 2012 survey (Fig. 12).

The species is very elusive and only 12 individuals have been observed, all in 1996. All individuals were observed in localities in the inundation zone, with soft bottom and/or leave litter, a normal habitat for species of the genus Pangio. It was also collected at the Nakai Dam site in 1996 and therefore expected for at least some distance in the Nam Theun downstream. Some individuals have a very dark colouration and this suggests that it possibly also inhabits crevices in rocks, as at the dam site. In such habitats they can be very difficult 


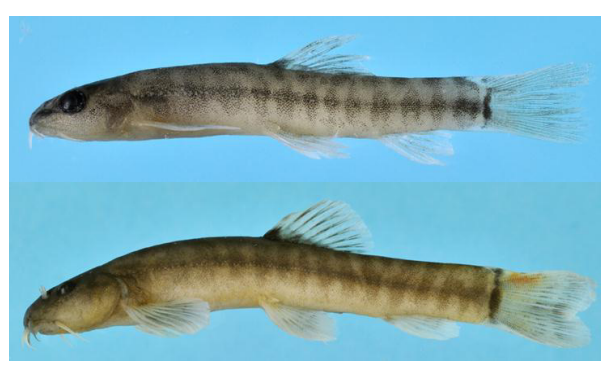

Fig. 13. Schistura sp. 'Nam Kathang'; juvenile, $22 \mathrm{~mm} \mathrm{SL}$ (above) and adult $59 \mathrm{~mm} \mathrm{SL}$ (below). Fig. 13. Schistura sp. 'Nam Kathang' ; juvénile, $22 \mathrm{~mm}$ LS (haut) et adulte $59 \mathrm{~mm}$ LS (bas).

to collect. The largest number of individuals in a single sample (5) was from a small forest stream near (old) Sop On village, in the inundation zone with soft bottom. It is expected to be present in small, permanent tributaries, with a low gradient.

There is a number of small forest creeks entering the Nam Theun between the Nakai Dam and the confluence with the Nam Phao that could home this species. On Nakai Plateau, the Nam On, which is inundated only for a short period every year, could also present suitable habitats for this species.

Because of its habitat and life habit, the absence of the species in surveys is not conclusive and suggests that the preferred habitat is missed by the sampling methods. Most species of this genus burrow in sand or mud and may escape ichthyocides if they are washed too quickly by the current.

\subsubsection{Schistura sp. 'Nam Kathang'}

Schistura sp. 'Nam Kathang' (Fig. 13) has been observed only in the Nam Kathang Gnai on Nakai Plateau. The Nam Kathang Gnai is flowing along the edge of the plateau but is not a tributary of the Nam Theun. Instead, it flows down the escarpment to the Xe Bangfai. It cannot be identified with any of the species known in the Nam Theun and Xe Bangfai drainages and is new to science and named Schistura sp. 'Nam Kathang' until given a formal name. This species is not affected by the inundation of the reservoir, but the new Ban Khonken village is located on and across the divide between the Nam Theun and Nam Kathang Gnai, and other villages are very close to the divide, so that disturbance of its habitat by villages is to be expected.

Species of the genus Schistura often have small distribution ranges, often limited to a single river drainage or subdrainage. For example most species present in the Nam Theun and Nam Gnouang are endemic to these rivers. However, it is not expected that this species would be restricted to the Nam Kathang Gnai but that it is probably present elsewhere in the Xe Bangfai drainage, probably together with Devario sp. 'green'.

Schistura sp. 'Nam Kathang' was observed at two sites in the Nam Kathang Gnai, accessed from Ban Khonken area, where the stream was very narrow and shallow, under forest cover, with a muddy to sand substrate, and Ban Done area where the stream had been forded, resulting in a deep pool upstream, very slow current and algae development on the bottom. There, the species was collected in the riffles at the level of the ford, which is the habitat of most species of Schistura.

Devario sp. 'green' and Schistura sp. 'Nam Kathang' are both known only from the Nam Kathang Gnai and 


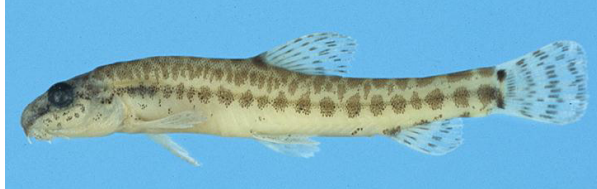

Fig. 14. Microcobitis aff. misgurnoides, $31 \mathrm{~mm} \mathrm{SL}$. Fig. 14. Microcobitis aff. misgurnoides, $31 \mathrm{~mm}$ LS.

attempts to find them outside the NTPC area failed. As the species seem to be impacted by resettlement activities, further studies are needed to determine their endemism. They should include the search for possible additional populations outside the Nakai Plateau.

\subsubsection{Microcobitis aff. misgurnoides}

Microcobitis aff. misgurnoides (Fig. 14) was first discovered during the 2007 survey. It is a still unnamed species related to Microcobitis misgurnoides, a species known only from Central Vietnam (Rendahl, 1944; Bohlen \& Harant, 2011). Morphology and molecular data show that they are distinct species.

Before inundation, Microcobitis aff. misgurnoides had been observed mostly in shallow lakes on the Nakai Plateau. A few individuals were found in the Nam Theun and the Nam On, in the inundation zone. It has never been observed further upriver. In 2007, it has also been observed in a drying river northeast of Laksao, which indicates that the species is not endemic to the Nakai Plateau.

It is a benthic species, living in soft bottom. Most individuals were obtained in samples that contained Oryzias species and Esomus metallicus, species that survive the dry season in the worst conditions in dry pools and swamps.

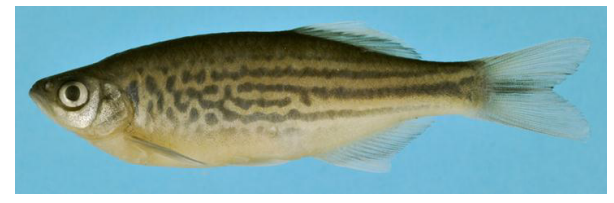

Fig. 15. Devario aff. quangbinhensis, $75 \mathrm{~mm} \mathrm{SL}$. Fig. 15. Devario aff. quangbinhensis, $75 \mathrm{~mm}$ LS.

This unpleasant habitat probably explains why it had been overlooked. However, it is not restricted to this habitat and was also collected in the Nam Theun and Nam On rivers at places with sand to muddy bottom. In the field it is easily confused with Lepidocephalichthys hasselti with which it co-occurs at all localities, in the same habitat.

Microcobitis aff. misgurnoides is now present in large numbers in sites in the inundation zone and is abundant in the mud bottom of pools connected with the reservoir at FSL.

\subsubsection{Devario aff. quangbinhensis}

While searching for Devario sp. 'green' in the Xe Bangfai drainage, another species of Devario was collected in the Nam Oula catchment (Fig. 15). This species cannot be identified with any of the species known in the Mekong drainage. It is possibly new to science and has an appearance similar to that of Devario quangbinhensis, a species described from Vietnam in the drainage of River Chay, in Quang Binh Province, which is adjacent to the $\mathrm{Xe}$ Bangfai drainage. The species was obtained in a small creek in the forest upstream of the limit of that stretch of the Nam Oula impacted by the increased flow and level in the Xe Bangfai.

However, further surveys are needed to determine its endemism. This includes 


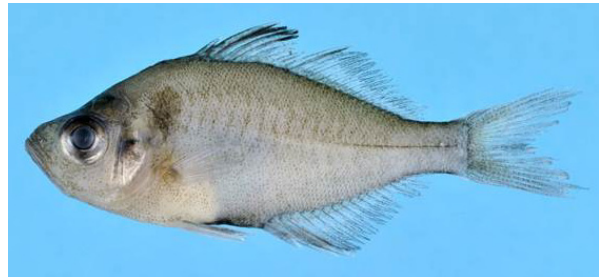

Fig. 16. Parambassis sp. 'slender', $43 \mathrm{~mm} \mathrm{SL}$. Fig. 16. Parambassis sp. 'slender', 43 mm LS.

the search for possible additional populations in the Xe Bangfai drainage and possibly in the Xe Banghiang.

\subsubsection{Parambassis sp. 'slender'}

The Parambassis (Fig. 16) species observed in the Nam Theun and Nam Gnouang drainages has similarities with Parambassis siamensis. However, it is possibly a distinct species because of its more elongated body.

This species was first observed in the Nang Gnouang in 2002 and in the Nam Phao in 2007. It was not present in the samples obtained between 1996 and 2009 immediately upstream of Keng Louang but it was very abundant in 2012 immediately downstream, where several hundreds were seen. Species of Parambassis elsewhere inhabit relatively slow and standing waters and the decreased flow in the Nam Theun and standing water in Theun Hinboun reservoir are likely to create more suitable environment for this species. Even if its endemic status is not yet confirmed it seems that no management measure is needed for this species other than a routine presence monitoring should be undergone in the Nam Theun River downstream.

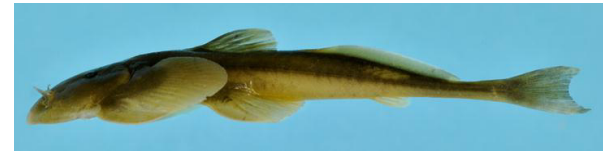

Fig. 17. Oreoganis lepturus, $53 \mathrm{~mm} \mathrm{SL}$.

Fig. 17. Oreoganis lepturus, $53 \mathrm{~mm}$ LS.

\subsubsection{Oreoglanis lepturus}

Oreoglanis lepturus (Fig. 17) is only known from the Nam Phao and might be present in the upstream Nam Gnouang. In the Nam Phao it has been observed in 1996 and 2006 only in the 1-2 km immediately downstream of the border between Laos and Vietnam, in a stretch with stones and boulders and small waterfalls, and in 2012 in the Nam Kata, in drying riffles.

Both sites are in sectors very impacted by human activity (e.g. irrigation network, road construction, gold mining, and fishing). However, the areas where the species was observed are not under the direct influence of the Nam Theun 2 project.

\subsubsection{Rhinogobius lineatus}

Rhinogobius lineatus (Fig. 18) is definitively known only from the Nam Theun downstream of the Nakai Dam and the Nam Gnouang. It was observed in 1996, 2002 and 2009.

The complete range of the species is impacted by Nam Theun 2 and Theun Hinboun activities. Most of the sites on the Nam Gnouang are now inundated by Theun Hinboun extension dam. On the Nam Theun, it was present in 2009 downstream (Keng Louang, Keng Iru) after completion of the Nakai Dam but was not seen in 2012. 


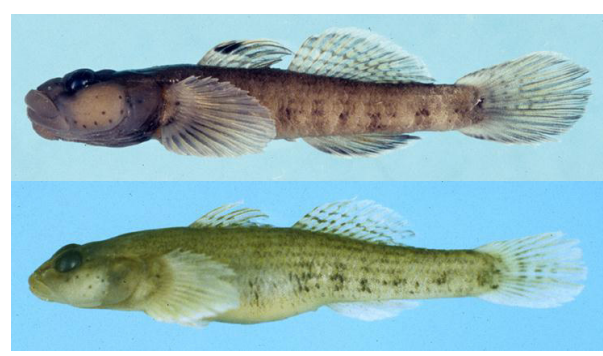

Fig. 18. Rhinogobius lineatus; male, $36 \mathrm{~mm} \mathrm{SL}$ (above) and female, $37 \mathrm{~mm} \mathrm{SL}$ (below).

Fig. 18. Rhinogobius lineatus; mâle, $36 \mathrm{~mm}$ LS (haut) et femelle, $37 \mathrm{~mm}$ LS (bas).

The genus Rhinogobius was collected only once in the Xe Bangfai in 2002, close to the downstream entrance of the underground course of the river. Unfortunately this individual was a female and the characters useful to identify species of Rhinogobius are mainly found in males. This female cannot be reliably identified, but it shows similarities with the females of Rhinogobius lineatus.

Survey should be conducted to obtain more material of the Xe Bangfai putative population and clarify whether or not it is Rhinogobius lineatus. It should also be searched in the subsisting small streams entering the Nam Gnouang and downstream Nam Theun. Its continued presence in Keng Iru and Keng Louang where it was seen in 2009 should be monitored. It is probably also present in the Nam Kading and its tributary streams.

\section{MODIFICATION OF FISH COMMUNITIES IN THE NAM THEUN 2 PROJECT AREA}

\subsection{Upper Nam Theun}

Sampling was conducted in the upper Nam Theun in 1996, 2003, 2006 and 2012; several sites were visited twice and one site was visited 3 times. In 2012, the situation of the aquatic habitats in the upstream Nam Theun above FSL has not changed significantly since the original 1996 survey. However the human population has increased and is more present along the river, with more houses and new hamlets. The river morphology does not seem to have changed although at least one site that earlier was a sand bank had become a bar of boulders, which seems a natural process, possibly the result of the 2011 storms.

No difference in the number of species and the composition of the fish communities was observed. This was expected since this stretch of the river is entirely within the NPA. However, the number of fish individuals seems lower and the size of the fishes seems smaller, suggesting overfishing.

The species diversity at the uppermost point that can be reached by boat was comparable to that of previous years: 23 species collected in 2012, 18 in 2006, 26 in 2003. But compared to earlier years, there was no large fish in 2012. Although no conclusion can be reached from a single sampling, this might reflect an increased fishing pressure. It might as well reflect that at this site the water was shallower and flowing over a much wider bed while in the previous years the rapids were narrower and deeper. Increased fishing pressure was also reported to be the cause of the rarefaction of large individuals of Luciocyprinus striolatus.

\subsection{Nakai Plateau}

The Nakai Plateau being now almost totally inundated part of the 
year, the riverine species, and especially the rheophilic ones, have disappeared. The species inhabiting the swamps are still present. Two are very abundant (Oryzias sp. 'river', Microcobitis aff. misgurnoides). A third one (Oryzias sp. 'swamp') was present in large numbers before inundation but is now rare and localised.

\subsection{Lower Nam Theun}

The closing of Nakai Dam resulted in a very reduced flow most of the year $\left(2 \mathrm{~m}^{3} / \mathrm{s}\right)$, and without variation. Parts of the rapids are now exposed, sand banks have become more extensive, etc. The species most specialised for rheophilic habitats become rarer and some are expected to disappear. Native species requiring slower water (e.g. Parambassis sp. 'slender') or sandy bottoms (e.g. Nemacheilus arenicolus) become more abundant.

The Keng Louang rapids on the lower Nam Theun were sampled in 1996, 2006, 2007, 2009 and 2012. The first four samples were obtained at exactly the same location. In 2012, the water level was so low that the river could be crossed in stepping from stone to stone; the earlier sampling site was exposed and another site had to be selected, not totally equivalent. Table III shows the species collected at Keng Louang in 1996, 2006 and 2007 before closure of the dam, and 2009 and 2012 after closure. The 2006 sample is indicative only; the identifications were based on field observations (the courier company destroyed the sample). The list of species shows great variation between the years. The 1996-2009 samples included 10 to 16 species, while the 2012 sample includes 23 species.

Five of the species observed in 2012 and absent in the samples of the previous years prefer slow flowing or even standing water (Cyclocheilichthys armatus, Esomus metallicus, Nemacheilus arenicolus, Parambassis sp. 'slender', Puntius brevis). Three species present in 2012 but not recorded earlier are specialist of fast waters (Garra cyrano, Balitoropsis yunnanensis, Schistura atra). A single species was present in all five samples (Poropuntius carinatus). Opsarius pulchellus was present in all previous samples but missing in 2012.

In the 2009 sample, 4 out of 14 species also had not been observed before and they were also species not usually associated with rapids (Devario fangfangae, Hemiculterella macrolepis, Neodontobutis aurarmus, Rasbora paviana). In 2009, two species typical of rapids and observed in all previous samples were missing (Garra theunensis, Scaphiodonichthys acanthopterus).

$A$ variation in the presence/absence or abundance of a species is normal and expected. The differences between the samples, however, is partly explained by the different location and different morphology of the sampling sites. The 2012 downstream site included a pool with little current at the time of the visit. Apparently this also confirms a shift towards a less rheophilic fish community already observed in 2009 after the closure of the Nakai Dam and the lower and extended dry season release. There is also indication that species from very slow or standing water of Theun-Hinboun reservoir may now be able to invade the lower Nam Theun. It 
Table III. Fish species collected in downstream Nam Theun at Keng Louang rapids between 1996 and 2012. Note: identifications for sample 2006 are based on field notes and the list is probably incomplete (see text). Samples from 1996 to 2009 were obtained at the same location at the upper edge of the rapids; in 2012 this point was emerged and the sample was obtained at mid height of the rapids.

Tableau III. Espèces de poissons de poissons récoltées dans la Nam Theun inférieure, aux rapides de Keng Louang entre 1996 et 2012. Note : les identifications de l'échantillonnage de 2006 sont basées sur les notes de terrain et sont probablement incomplètes (voir texte). Les échantillons de 1996 à 2009 on été obtenus au même emplacement au bord supérieur des rapides ; en 2012 cet emplacement était émergé et l'échantillon a été obtenu à mi-hauteur des rapides.

\begin{tabular}{|c|c|c|c|c|c|}
\hline Species & 1996 & 2006 & 2007 & 2009 & 2012 \\
\hline Balitora lancangjiangensis & & & $x$ & $\mathrm{x}$ & \\
\hline Balitoropsis yunnanensis & & & & & $x$ \\
\hline Cirrhinus molitorella & & & $x$ & & \\
\hline Cycloceilichthys armatus & & & & & $\mathrm{x}$ \\
\hline Devario fangfangae & & & & $x$ & \\
\hline Esomus metallicus & & & & & $x$ \\
\hline Garra cambodgiensis & & $x$ & $x$ & $x$ & $x$ \\
\hline Garra cyrano & & & & & $x$ \\
\hline Garra theunensis & $x$ & $x$ & $x$ & & $x$ \\
\hline Glyptothorax laosensis & & $x$ & $x$ & & \\
\hline Glyptothorax horai & & $\mathrm{x}$ & & $\mathrm{x}$ & \\
\hline Glyptothorax aff. zanaensis & & & $x$ & $x$ & $x$ \\
\hline Gyrinocheilus aymonieri & & & $x$ & $x$ & $x$ \\
\hline Hampala macrolepidota & & & & & $x$ \\
\hline Heminagrus wyckioides & & $x$ & & & $x$ \\
\hline Hemiculterella macrolepis & & & & $x$ & \\
\hline Hemimyzon papilio & & & $x$ & & \\
\hline Homalopteroides smithi & $\mathrm{x}$ & $\mathrm{x}$ & & $x$ & \\
\hline Mastacembelus armatus & & & & $x$ & $x$ \\
\hline Mystacoleucus marginatus & & & $x$ & & $\mathrm{x}$ \\
\hline Nemacheilus arenicolus & & & & & $x$ \\
\hline Neodontobutis aurarmus & & & & $x$ & \\
\hline Onychostoma fusiforme & & & $x$ & & \\
\hline Opsarius pulchellus & $\mathrm{x}$ & $x$ & $x$ & $x$ & \\
\hline Papuligobius ocellatus & $x$ & $x$ & $x$ & & $x$ \\
\hline Parambassis sp. 'slender' & & & & & $x$ \\
\hline Poropuntius carinatus & $x$ & $x$ & $x$ & $x$ & $x$ \\
\hline Puntius brevis & & & & & $\mathrm{x}$ \\
\hline Rasbora paviana & & & & $x$ & $\mathrm{x}$ \\
\hline Rhinogobius lineatus & $x$ & & & & \\
\hline Scaphiodonichthys acanthopterus & $x$ & $x$ & $x$ & & $x$ \\
\hline Schistura atra & & & & & $x$ \\
\hline Schistura cataracta & $x$ & & $x$ & $x$ & $x$ \\
\hline Schistura kongphengi & $x$ & & & & $x$ \\
\hline Schistura obeini & & & $\mathrm{x}$ & & \\
\hline Tor tambra & $x$ & & & & $x$ \\
\hline Total & 10 & 10 & 16 & 14 & 23 \\
\hline
\end{tabular}


also cannot be excluded that some of these species were not native but introduced in Theun Hinboun Reservoir.

\subsection{Nam Phao}

The Nam Phao (and its branch Nam Kata) is the only tributary of the Nam Theun downstream of Nakai Dam. It was expected that these rivers could serve as refuges for juvenile and smallsized species. Unfortunately, these tributaries suffer great anthropogenic impacts. Some have been observed since the beginning of the monitoring in 1996 (e.g. the formation of large sand banks and filling of all deep holes of the Nam Phao, a result of the construction of a small dam upstream of Laksao and of road work). The number of species obtained by the 2012 survey and the number and size of the individuals seems lower. The number of samples is probably too low to reach an objective conclusion.

The situation of the Nam Kata did not differ between 2002 and 2012 in the visited stretch. The Nam Kata suffers of strong sedimentation and is heavily impacted by mining and the related pollution, water abstraction, eutrophication, and possibly pesticides. At each visit, the fish densities were low and the fish collected were all juveniles or are small-sized species.

\subsection{Downstream Xe Bangfai}

The modified water conditions make it impossible to replicate the sampling done in 1996 and 2006. In addition sampling in the Xe Bangfai itself is now much more difficult because of the higher water level and greater discharge. Effective sampling in the river itself is possible only with the local seines and local population. In 2012, suitable conditions were present in Ban Boungxe, a site already sampled in 2006.

In 2012, 28 fish species were obtained in water less than about 2 meters deep, by seine over sandy bottom. This compares with 25 species obtained in 2006 in the same area. In the same area, the 1996 sampling had yielded 40 species near the confluence with the Mekong and 38 on a 7-km stretch downstream of the bridge at Ban Khouaxe. The combined total number of species of these two samples was 57 . The number of species was considerably higher but the 1996 samples involved more workers, longer seines ( $200 \mathrm{~m}$ vs. $50 \mathrm{~m}$ ), lasted a whole day each, and included various habitats (mud, clay, sand, gravel bar, backwaters etc.) while only sand was available at the site sampled in 2012.

Nine species out of 28 (32\%) obtained at the 2012 site had not been observed in the same area by the 1996 and 2006. Among them, 4 species had not been recorded in the Xe Bangfai before, and one (Acantopsis sp. 'dwarf males') is possibly new to science.

That a single sample in 2012 included $1 / 3$ of species not observed before in that part of the river with a similar methodology indicates that the fish fauna of the lower part of the river is still undersampled, that more sampling should be conducted. In fact the various surveys have taken only 7 samples in the Xe Bangfai itself downstream of the bridge (Ban Khouaxe) 
between 1996 and 2012. It is also expected that sampling at the same site at different times of the year would yield different species. Sampling by night would also add a number of species, especially catfishes.

No conclusion on the impact of NTPC activity on the fish diversity of that stretch of the Xe Bangfai can be derived from this sampling.

Two samples were obtained in the Xe Noy, a main tributary of the Xe Bangfai, at and above the maximum extent of the water backed up by the increased flow of the Xe Bangfai. A combined total of 48 species was obtained. The observed fish community is representative of what was known in the Xe Bangfai in similar habitats between Mahaxai and the confluence with the Nam Phit.

\section{DISCUSSION - CONCLUSION}

\subsection{Fish biodiversity}

Detailed surveys before construction allowed to identify the biodiversity important species and to focus attention on them during monitoring.

The fish fauna of the Nam Theun and the Xe Bangfai are strikingly different. There is an obvious difference in richness, with 74 native species in the Nam Theun drainage and 178 in the Xe Bangfai drainage. Part of the difference results from the different purposes of the various samplings, which imposed priorities and geographical limits: while the Xe Bangfai was surveyed for its whole length, from the headwaters to the Mekong, the Nam Theun is only the upper part of the Nam Kading drainage and no lowland and floodplain habitats were included in the surveys. On the reverse, the coverage for the upper part of the Xe Bangfai is very limited and the sampling on the whole river was less dense than on the Nam Theun.

Despite these reservations, our surveys show that the Nam Theun has fewer species than the Xe Bangfai but that $21(28 \%)$ of the 74 native species are endemic. It might be that some of these species await to be discovered in other tributaries of Nam Kading and in the Nam Xan drainage north of the Nam Theun. Besides, as mentioned above, a number of species of the Nam Theun are closely related with species and genera otherwise known only from the other side of the Annamite Range and unknown or with very restricted ranges in the Mekong drainage. The fauna of the Nam Theun has more similarities with that of the drainages to the north.

On the other hand, only $9(5 \%)$ of the 178 species reported from the $\mathrm{Xe}$ Bangfai are endemic. The Xe Bangfai fish fauna is similar to the fauna of the Mekong major tributaries to the South, in Laos and Thailand. Three of the 'endemics' were discovered by the 2012 survey in habitats still insufficiently sampled in other drainages and some are expected to be discovered there too.

The majority of the Nam Theun fish species inhabit rapids and very fast waters (rheophilic habitats), with some (Oreoglanis spp., Pseudecheneis sympelvica) present even in waterfalls. Many of these species have developed structures that allow them to keep position in strong current, like laterally expanded fins, fins fused to form a sucker, sucking mouth, gill opening 
modification allowing to inhale and exhale water, tubercles on the snout to reduce the pressure of the current, jaws with a sharp cutting edge to scrape algae from the surface of the stones, skin lamellae on the belly with a structure similar to the sucking disk of remoras, etc. The Xe Bangfai has very few species with such structures (but this may partly reflect that suitable habitats could not be reached).

To date, a single species of the $\mathrm{Xe}$ Bangfai is also known, or is closely related to a species, from the other slope of the Annamite Range in Vietnam (Devario aff. quangbinhensis), although the divide between the two slopes is very low (about 400 masl).

The swamp and marsh habitats of the Nam Theun and Xe Bangfai drainages also differ conspicuously. The swamp habitats of the Xe Bangfai are in the Mekong floodplain and have a rich fauna, made mostly of species present throughout the floodplain of the middle Mekong, with no endemic. On the other hand, the swamp habitats in the Nam Theun are located on Nakai Plateau. They are fed by rain and by the cool water of the Nam Theun. They have a very small number of species but three of them are endemic, and two only known from the inundation zone.

\subsection{Status of Nam Theun endemic fishes}

The construction of dams and reservoirs unavoidably has severe impacts on aquatic habitats and aquatic biodiversity. The impact on rheophilic species could be a serious issue because these species not only have a limited distribution within a drainage, but also because the ranges of rheophilic species are restricted to a few or a single drainage. Because of its morphology, the Nam Theun has a fauna mostly rheophilic (38 out of 74 species), of which $13(34 \%)$ are endemic (or endemic to the Nam Theun + Nam Gnouang). In other words, $1 / 6$ of the fish species of the Nam Theun were potentially threatened of extinction by the project.

The rivers upstream of the Nakai Reservoir are large and diverse enough to provide habitats to all but two of the endemic rheophilic species. These habitats are within the NPA and therefore supposedly safe at the short and medium term. Since no long-distance migratory species was found (and none was reported by the local population) the dam is not a barrier threatening the life cycle of any migratory species. Further, downstream of Nakai Reservoir, the river was already blocked by TheunHinboun Dam.

The future of one rheophilic species not observed upstream of the reservoir (Scaphognathops theunensis) is dimmer. At the time the surveys were conducted, a significant share of its range was in the Nam Gnouang and it seemed to be reasonably safe. However, between the time the surveys were conducted and the construction of the Nakai Dam, an extension dam for the Theun-Hinboun Reservoir was built on the Nam Gnouang, flooding the remaining intact habitat of the species. This underlines the need of a basinwide management of aquatic biodiversity. The other endemic rheophilic species not present upstream of Nakai Reservoir (Rhinogobius lineatus) is a smaller fish with different habitat 
requirements. Although still a biodiversity important species, it seems in a safer situation with its range apparently extending above FSL of the TheunHinboun extension Reservoir.

The rivers in the NPA are presently the best known remaining habitat for the endangered Luciocyprinus striolatus and potentially the only one where the species has chances to survive. This assumes that the aquatic habitats be managed with the same attention as terrestrial habitats.

While most of the original habitat of the species endemic to the swamps of Nakai Plateau is inundated, two are abundant along the shores of the reservoir and do not seem of concern. The third one (Oryzias sp. 'swamp') had become very rare and has now been rediscovered and is the subject of specific studies and its future is now expected to be safer.

The status of Rhodeus laoensis is not clear. It has been recorded upstream of Nakai Reservoir, but only juveniles and at low density. The supposed host mussel is rare and in places in the NPA where juvenile bitterlings had been collected the villagers were not even aware of the presence of mussels. The two species need more attention. The objective identification of the host is needed (by confirming the presence of fish larvae in the mussel).

To conclude, the survival of some of the endemic species may require additional measures, such as establishing conservation zones and specific fishing regulations. Obviously, this can be successful only with communication with the local population.

\section{ACKNOWLEDGMENTS}

The research summarised here results from several surveys conducted for the Nam Theun 2 Power Company (NTPC) in Lao PDR whose shareholders are Electricité de France, Lao Holding State Enterprise, and Electricity Generating Public Company Limited of Thailand.

Over the year, I benefitted from the support of many managers and staff of NTPC, especially in the early years François Obein and Peter Goldston. Likewise, the field work would not have been successful without the assistance of a great number of villagers, local workers, NTPC staff (especially Phouthakone Luangyotha, Stuart Gillon, Khamkeng Yuena), researchers and staff of LARREC (Kongpheng Bouakhamvongsa, Sinthawong Viravong, Khamtanh Vatthanatham) and other collaborators (Soutchai Khamphousay, Tan Heok Hui, Leong Tzi Ming). I thank Katsuma Kubota (Bangkok) for providing information on spawning of Oryzias sp. 'swamp'; Arthur E. Bogan (North Carolina State Museum of Natural Sciences, Raleigh) for identification of the mussels; Liankham Payasane (NTPC) for designing the map; and Maud Cottet (NTPC) for various information and data and for her help to organise and finalise this article.

\section{REFERENCES}

Akai Y., Suzuki N., Masuda O. \& Akiyama N., 2005. All about bitterlings - Fishing, keeping, breeding. MPJ. Tokyo: $159 \mathrm{p}$.

Baird I.G., Inthaphaisy V., Kisouvannalath P., Phylavanh B. \& Mounsouphom B., 1999. The fishes of southern Lao. Lao 
Community Fisheries and Dolphin Protection Project. Pakse: 160 p.

Bogan A.E., 1993. Freshwater bivalve extinctions (Mollusca: Unionoida): a search for causes. American Zoologist 33 : 599-609.

Bogan A.E., 2006. Conservation and extinction of the freshwater molluscan fauna of North America. In: Sturm C.F., Pearce T.A. \& Valdés A. (Eds.), The mollusks: a guide to their study, collection, and preservation, 373-383, Universal Publishers, Boca Raton.

Bohlen J. \& Harant R., 2011. Microcobitis, a new genus name for Cobitis misgurnoides (Teleostei: Cobitidae). Ichthyological Exploration of Freshwaters 21(4) : 295-300.

Brandt R.A.M., 1974. The non-marine aquatic Mollusca of Thailand. Archiv für Molluskenkunde 105 : 1-423.

Britz R. \& Kottelat M., 1999a. Two new species of gasterosteiform fishes of the genus Indostomus (Teleostei: Indostomidae). Ichthyological Exploration of Freshwaters 10(4) : 327-336.

Britz R. \& Kottelat M., 1999b. Sundasalanx mekongensis, a new species of clupeiform fish from the Mekong basin (Teleostei: Sundasalangidae). Ichthyological Exploration of Freshwaters 10(4) : 337344.

Britz R. \& Kottelat M., 2010. Pangio longimanus, a miniature species of eel-loach from Central Laos (Teleostei: Cypriniformes: Cobitidae). Ichthyological Exploration of Freshwaters 20(4) : 371-376.

Britz R. \& Maclaine J., 2007. A review of the eel-loaches, genus Pangio, from Myanmar (Teleostei: Cypriniformes: Cobitidae). Ichthyological Exploration of Freshwaters 18(1) : 17-30.

Chen I.-S. \& Kottelat M., 2000. Rhinogobius maculicervix, a new species of goby from the Mekong basin in northern Laos
(Teleostei: Gobiidae). Ichthyological Exploration of Freshwaters 11(1) : 81-87.

Chen I.-S., Kottelat M. \& Miller P. J., 1999. Freshwater gobies of the genus Rhinogobius from the Mekong basin in Thailand and Laos, with descriptions of three new species. Zoological Studies 38(1) : 19-32.

Cottet M., Descloux S., Guédant P., Cerdan P. \& Vigouroux R. Fish population dynamic in the newly impounded Nam Theun 2 Reservoir (Lao PDR). Hydroécologie Appliquée 19 (same issue).

Cupet P., 1900. Voyages au Laos et chez les sauvages du Sud-Est de I'Indo-Chine. In: Pavie A. (Ed.), Mission Pavie IndoChine 1879-1895 - Géographie et voyages. Leroux. Paris: 425 p., 15 pls [Translation by W.E.J. Tips, 2000. The Pavie Mission Indochina papers 18791895 - Volume 6. Travels in Laos and among the tribes of Southeast Indochina. White Lotus. Bangkok: xii+446 p.].

Fang F. \& Kottelat M., 1999. Danio species from northern Laos, with descriptions of three new species (Teleostei: Cyprinidae). Ichthyological Exploration of Freshwaters 10(3) : 281-295.

Fang F. \& Kottelat M., 2000. Danio roseus, a new species from the Mekong basin in northeastern Thailand and northwestern Laos (Teleostei: Cyprinidae). Ichthyological Exploration of Freshwaters 11(2) : 149-154.

Hennache A. \& Dickinson E.C., 2000. Les types d'oiseaux rapportés du Vietnam, du Laos et du Cambodge par Jean Delacour entre 1923 et 1939. Zoosystema 22 : 601-629.

Kitamura J., 2007. Reproductive ecology and host utilization of four sympatric bitterlings (Acheilognathinae, Cyprinidae) in a lowland reach of the Harai River in Mie, Japan. Environmental Biology of Fishes 78 : 37-55. 
Kottelat M., 1984. A review of the species of Indochinese fresh-water fishes described by H.-E. Sauvage. Bulletin du Muséum National d'Histoire Naturelle, Paris, Sect. A, Sér. 4, 6(3) : 791-822.

Kottelat M., 1989. Zoogeography of the fishes from Indochinese inland waters with an annotated check-list. Bulletin Zoölogisch Museum Universiteit van Amsterdam 12(1) : 1-54.

Kottelat M., 1996. Potential impacts of Nam Theun 2 hydropower project on the fish and aquatic fauna of the Nam Theun and Xe Bangfai basins, Lao P.D.R. Report prepared for Nam Theun 2 Electricity Consortium, Vientiane.

Kottelat M., 1997. Distribution of the fishes previously considered endemic to the Nam Theun and Xe Bangfai basins, Lao P.D.R. Report prepared for Nam Theun 2 Electricity Consortium, Vientiane.

Kottelat M., 1998. Fishes of the Nam Theun and Xe Bangfai basins, Laos, with diagnoses of twenty-two new species (Teleostei: Cyprinidae, Balitoridae, Cobitidae, Coiidae and Odontobutidae). Ichthyological Exploration of Freshwaters 9(1) : 1-128.

Kottelat M., 2000. Diagnoses of a new genus and 64 new species of fishes from Laos (Teleostei: Cyprinidae, Balitoridae, Bagridae, Syngnathidae, Chaudhuriidae and Tetraodontidae). Journal of South Asian Natural History 5(1) : 37-82.

Kottelat M., 2001. Fishes of Laos. Wildlife Heritage Trust. Colombo: $198 \mathrm{p}$.

Kottelat M., 2002. Distribution and status of the fishes previously considered endemic to the Nam Theun basins, Lao P.D.R. Report prepared for Nam Theun 2 Electricity Consortium, Vientiane.

Kottelat M., 2004. Distribution and life history of the fishes Tor ater and Scaphognathops theunensis in the Nam Theun basin, Lao P.D.R. Report prepared for
Nam Theun 2 Electricity Consortium, Vientiane.

Kottelat M., 2006. Fish and aquatic habitats survey in NTPC area, 2006. Report prepared for Nam Theun 2 Power Company, Vientiane.

Kottelat M., 2007. Fish and fish communities. In: Dersu (Ed.), Baseline inventory - Wildlife and habitat studies of the Nakai Plateau, 25-51, 270-285. Report prepared for Nam Theun 2 Power Company, Vientiane.

Kottelat M., 2009. Post-inundation fish biodiversity survey. Report prepared for Nam Theun 2 Power Company, Vientiane.

Kottelat M., 2012a. DNA analysis of Oryzias specimens. Report prepared for Nam Theun 2 Power Company, Vientiane.

Kottelat M., 2012b. Interdependant conservation of bitterlings and mussels. In: Allen D.J., Smith K.G. \& Darwall W.R.T. (Eds.), The status and distribution of freshwater biodiversity in Indo-Burma, 63, International Union for Conservation of Nature [IUCN]. Cambridge \& Gland.

Kottelat M., 2012c. Conspectus cobitidum: an inventory of the loaches of the world (Teleostei: Cypriniformes: Cobitoidea). Raffles Bulletin of Zoology Supplement $26: 1$-199.

Kottelat M., 2013a. Post impoundment fish biodiversity survey. Final Report. Report prepared for Nam Theun 2 Power Company, Vientiane.

Kottelat M., 2013b. The fishes of inland waters of Southeast Asia: a catalogue and core bibliography of the fishes known to occur in freshwaters, mangroves and estuaries. Raffles Bulletin of Zoology Supplement 27 : 1-663.

Kottelat M. \& Bréhier F., 1999. Troglocyclocheilus khammouanensis, a new genus and species of cave fish from the Khammouan karst, Laos (Teleostei: Cyprinidae). 
Revue Suisse de Zoologie 106(2) : 347359.

Kottelat M. \& Ng H.H., 1999. Belodontichthys truncatus, a new species of silurid catfish from Indochina (Teleostei: Siluridae). Ichthyological Exploration of Freshwaters 10(4) : 387-391.

Kottelat M. \& Steiner H., 2011. Bangana musaei, a new cave fish from central Laos (Teleostei: Cyprinidae). Ichthyological Exploration of Freshwaters 21(4) : 313-322.

Kottelat M. \& Whitten A.J., 1996. Freshwater biodiversity in Asia with special reference to fish. World Bank Technical Paper 343 : ix +59 p.

Kottelat M., Baird I.G., Kullander S.O., Ng H.H., Parenti L.R., Rainboth W.J. \& Vidthayanon C., 2012. The status and distribution of freshwater fishes of IndoBurma. In: Allen D.J., Smith K.G. \& Darwall W.R.T. (Eds.), The status and distribution of freshwater biodiversity in Indo-Burma, 38-65, International Union for Conservation of Nature [IUCN]. Cambridge \& Gland.

Liu H.-Z., Zhu Y.-R., Smith C. \& Reichard M., 2006. Evidence of host specificity and congruence between phylogenies of bitterling and freshwater mussels. Zoological Studies 45(3) : 428-434.

Macey P., 1908. Cours d'eau souterrains du Cammon au Laos. Spelunca, Bulletin et Mémoires de la Société de Spéléologie $7: 151-175$.

Macey P., 1911. Tunnels naturels du Laos. La Nature 39 : 102-106.

Mouret C., Collignon B., Vacquié J.-F. \& Lagarde C., 1996. La Xé Bang Fai souterraine. Spelunca $62:$ 20-22.

MouretC., Brouquisse F., Lordon J. \& Vacquié J.-F., 1997a. Laos - Explorations 1997 dans la province de Khammouane. Spelunca $68: 5-9$.
Mouret C., Collignon B. \& Vacquié J.F., 1997b. Giant underground rivers in Central Laos. Proceedings of the 12th International Congress of Speleology, La Chaux-de-Fonds, Switzerland 4 : 57-60.

Mouret C., Vaquié J.-F., Collignon B., Rolin J. \& Steiner H., 2010. La rivière souterraine géante de Tham Xe Bang Fai et le réseau karstique associé, Aire nationale protégée de Hin Namno, Khammouane, Laos central. Spelunca 119 : 35-45.

Ng H.H., 1999a. Pterocryptis inusitata, a new species of silurid catfish from Laos (Teleostei: Siluriformes). Ichthyological Exploration of Freshwaters 10(4) : 371374.

$\mathrm{Ng} \mathrm{H.H.,} \mathrm{1999b.} \mathrm{Laides} \mathrm{longibarbis,} \mathrm{a} \mathrm{valid}$ species of schilbeid catfish from Indochina (Teleostei: Siluriformes). Ichthyological Exploration of Freshwaters 10(4) : 381-385.

Ng H.H. \& Kottelat M., 1998. The catfish genus Akysis Bleeker (Teleostei: Akysidae) in Indochina, with descriptions of six new species. Journal of Natural History 32 : 1057-1097.

$\mathrm{Ng} \mathrm{H.H.} \mathrm{\&} \mathrm{Kottelat} \mathrm{M.,} \mathrm{1999.} \mathrm{Oreoglanis}$ hypsiurus, a new species of glyptosternine catfish (Teleostei: Sisoridae) from Laos. Ichthyological Exploration of Freshwaters 10(4) : 375-380.

Ng H.H. \& Kottelat M., 2000a. Descriptions of three new species of catfishes (Teleostei: Akysidae and Sisoridae) from Laos and Vietnam. Journal of South Asian Natural History 5(1) : 7-15.

$\mathrm{Ng} \mathrm{H.H.} \mathrm{\&} \mathrm{Kottelat} \mathrm{M.,} \mathrm{2000b.} \mathrm{A} \mathrm{review} \mathrm{of}$ the genus Amblyceps (Osteichthyes: Amblycipitidae) in Indochina, with descriptions of five new species. Ichthyological Exploration of Freshwaters 11(4) : 335-348.

$\mathrm{Ng} \mathrm{H.H.} \mathrm{\&} \mathrm{Kottelat} \mathrm{M.,} \mathrm{2000c.} \mathrm{Helicophagus}$ leptorhynchus, a new species of molluscivorous catfish from Indochina (Teleostei: 
Pangasiidae). Raffles Bulletin of Zoology 48(1) : 55-58.

Pellegrin J., 1936. Poissons nouveau du HautLaos et de l'Annam. Bulletin de la Société Zoologique de France 56 : 243-248.

Pellegrin J. \& Fang P. W., 1940. Poissons du Laos recueillis par MM. Delacour, Greenway, Ed. Blanc. Description d'un genre, de cinq espèces et d'une variété. Bulletin de la Société Zoologique de France 65 : 111-123.

Pollack J. \& Osburn B., 2006. Xe Bang Fai: giant river cave of Laos. National Speleological Society News 64(5) : 12-13; 31.

Pollack J., Kambesis P., Osburn B., Bunnell D., Addison A., Stanway K., Sawatzky D. \& Whitfield P., 2009. Lao People's Democratic Republic (PDR). Tham Khoun $\mathrm{Xe}$ - the great cave on the Xe Bang Fai River. National Speleological Society News 67(7) : 4-19.

Rendahl H., 1944. Einige Cobitiden von Annam und Tonkin. Göteborgs Kungliga Vetenskaps och Vitterhets Samhällas Handlingar, Series B, Matematiska och Naturvetenskapliga Skrifter 3(3) : 1-54.

Roberts T.R., 1993. Artisanal fisheries and fish ecology below the great waterfalls of the Mekong river in southern Laos. Natural History Bulletin of the Siam Society 41 : 31-62.

Roberts, T.R., 1995. Botia splendida, a new species of loach (Pisces: Cobitidae) from the Mekong basin in Laos. Raffles Bulletin of Zoology 43(2) : 463-467.

Roberts T.R., 1997. Serpenticobitis, a new genus of cobitid fishes from the Mekong basin, with two new species. Natural History Bulletin of the Siam Society 45(1) : 107-115.

Roberts T.R., 1998a. Systematic revision of the balitorid loach genus Sewellia of
Vietnam and Laos, with diagnoses of four new species. Raffles Bulletin of Zoology 46(2) : 271-288.

Roberts T.R., 1998b. Systematic observations on tropical Asian medakas or ricefishes of the genus Oryzias, with descriptions of four new species. Ichthyological Research 45(3) : 213-224.

Roberts T.R., 1999. Fishes of the cyprinid genus Tor in the Nam Theun watershed (Mekong basin) of Laos, with description of a new species. Raffles Bulletin of Zoology 47(1) : 225-236.

Sauvage H.-E., 1878. Note sur quelques poissons d'espèces nouvelles provenant des eaux douces de I'Indo-Chine. Bulletin de la Société Philomathique de Paris Sér. 7, 2 : 233-242.

Sauvage H.-E., 1880. Notice sur quelques poissons de l'île Campbell et de I'IndoChine. Bulletin de la Société Philomathique de Paris Sér. 7, 4 : 228-233.

Sérène R., 1951. Sur la faune ichtyologique du Laos. Indo-Pacific Fisheries Council, 3rd Meeting, Madras, IPFC/C51/TECH $49: 1-26$.

Taki Y., 1974. Fishes of the Lao Mekong basin. U.S.A.I.D. Mission to Laos. Vientiane: $232 \mathrm{p}$.

Vidthayanon C. \& Jaruthanin K., 2002. Schistura kaysonei, (Teleostei: Balitoridae) a new cave fish from the Khammouan karst, Laos PDR. Aqua Journal of Ichthyology and Aquatic Biology 6(1) : 17-20.

Watters G.T., 2000. Freshwater mussels: a complicated resource to conserve. In Freshwater ecoregions of North America - a conservation assessment. R. A. Abell et al. : 37-39. Island Press, Washington. 
The fishes of the Nam Theun and Xe Bangfai drainages, Laos

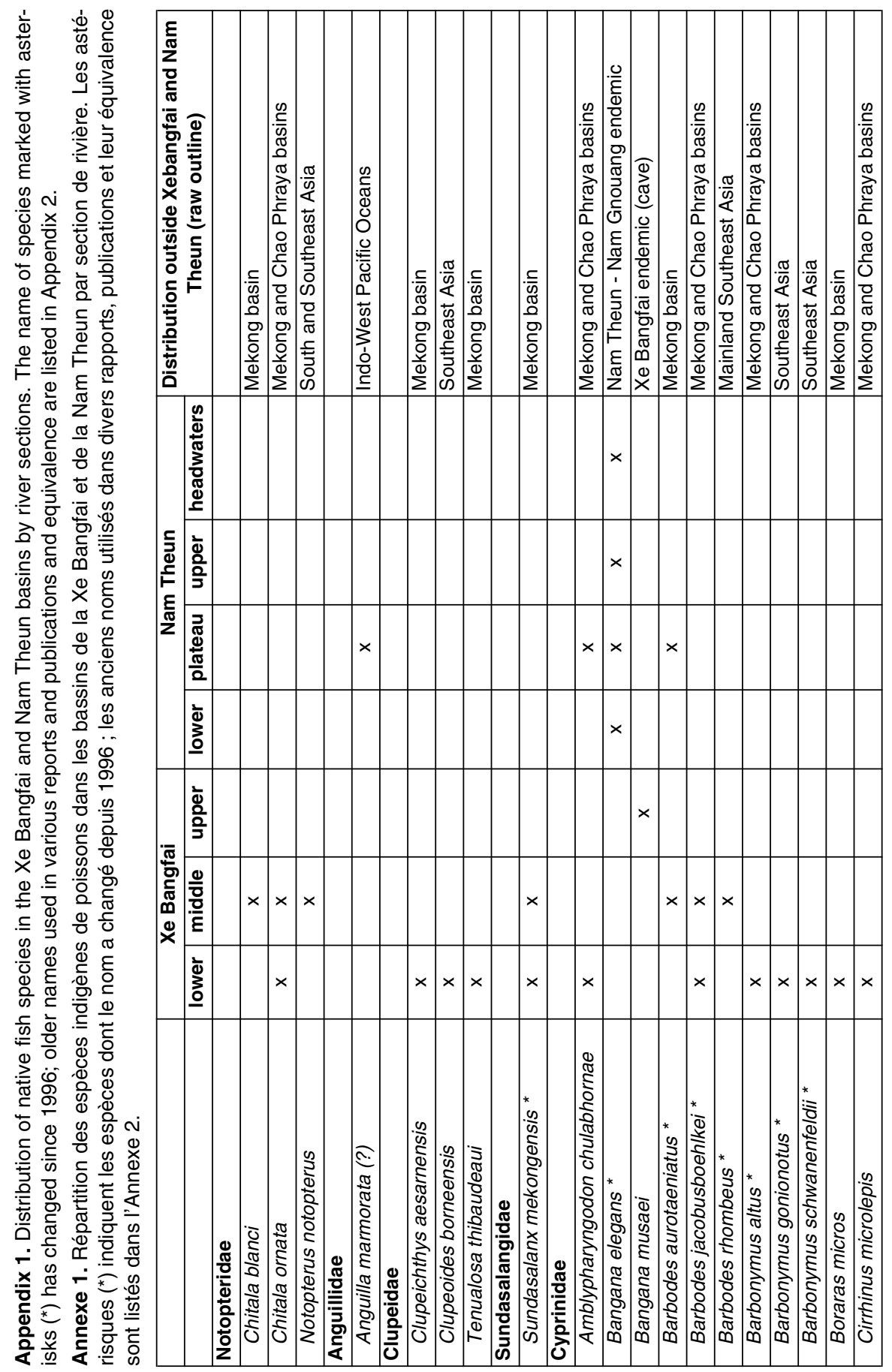




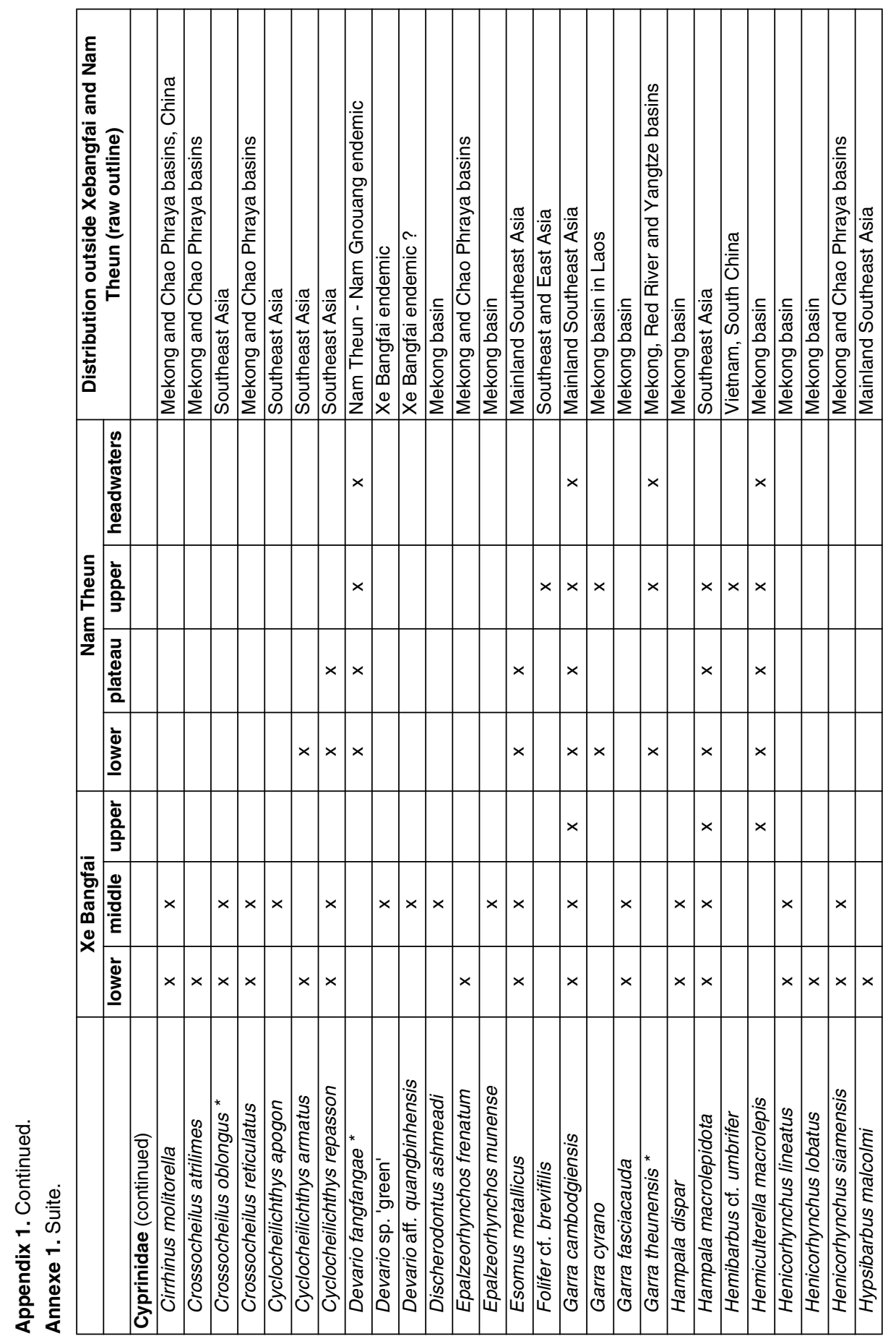




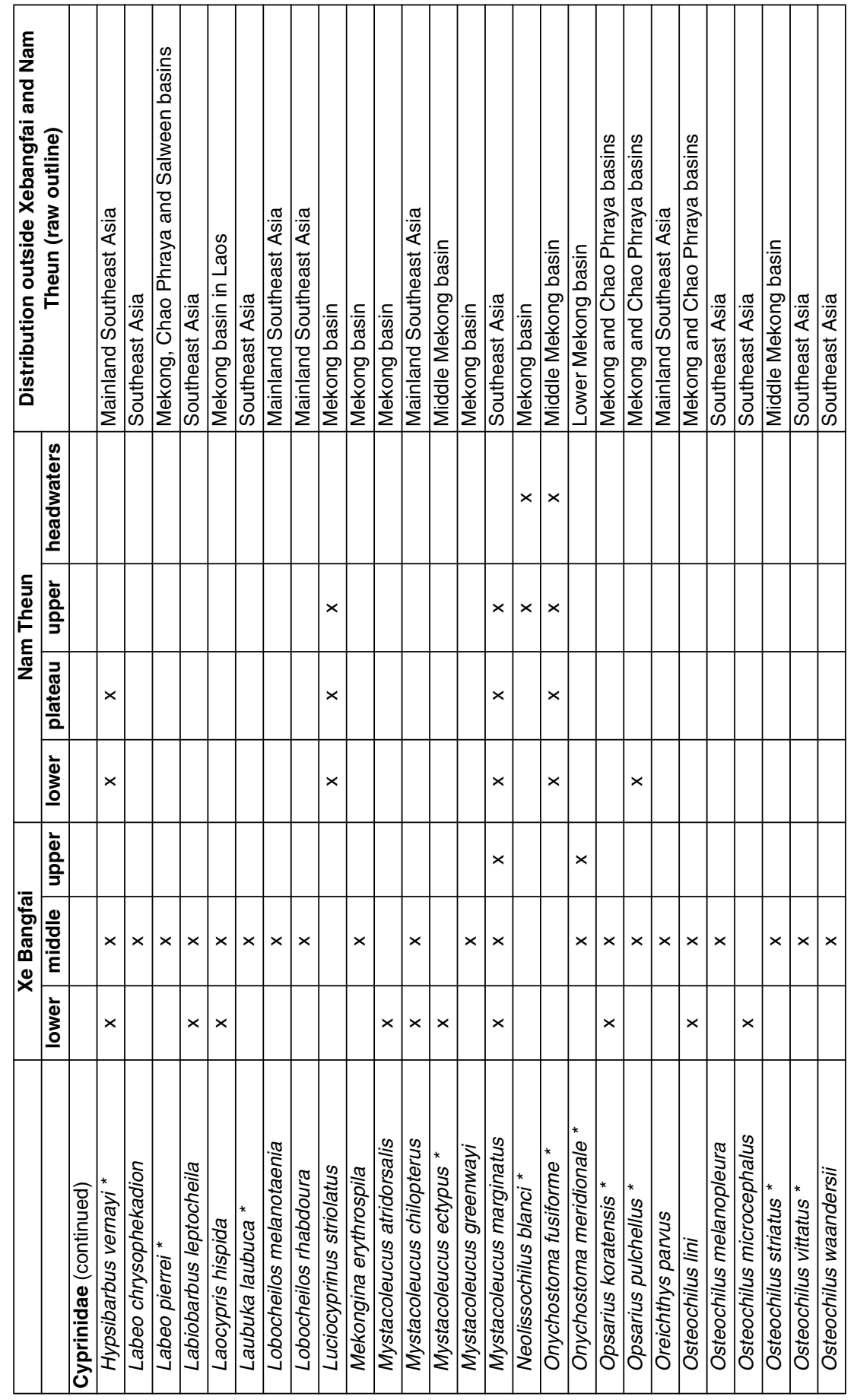




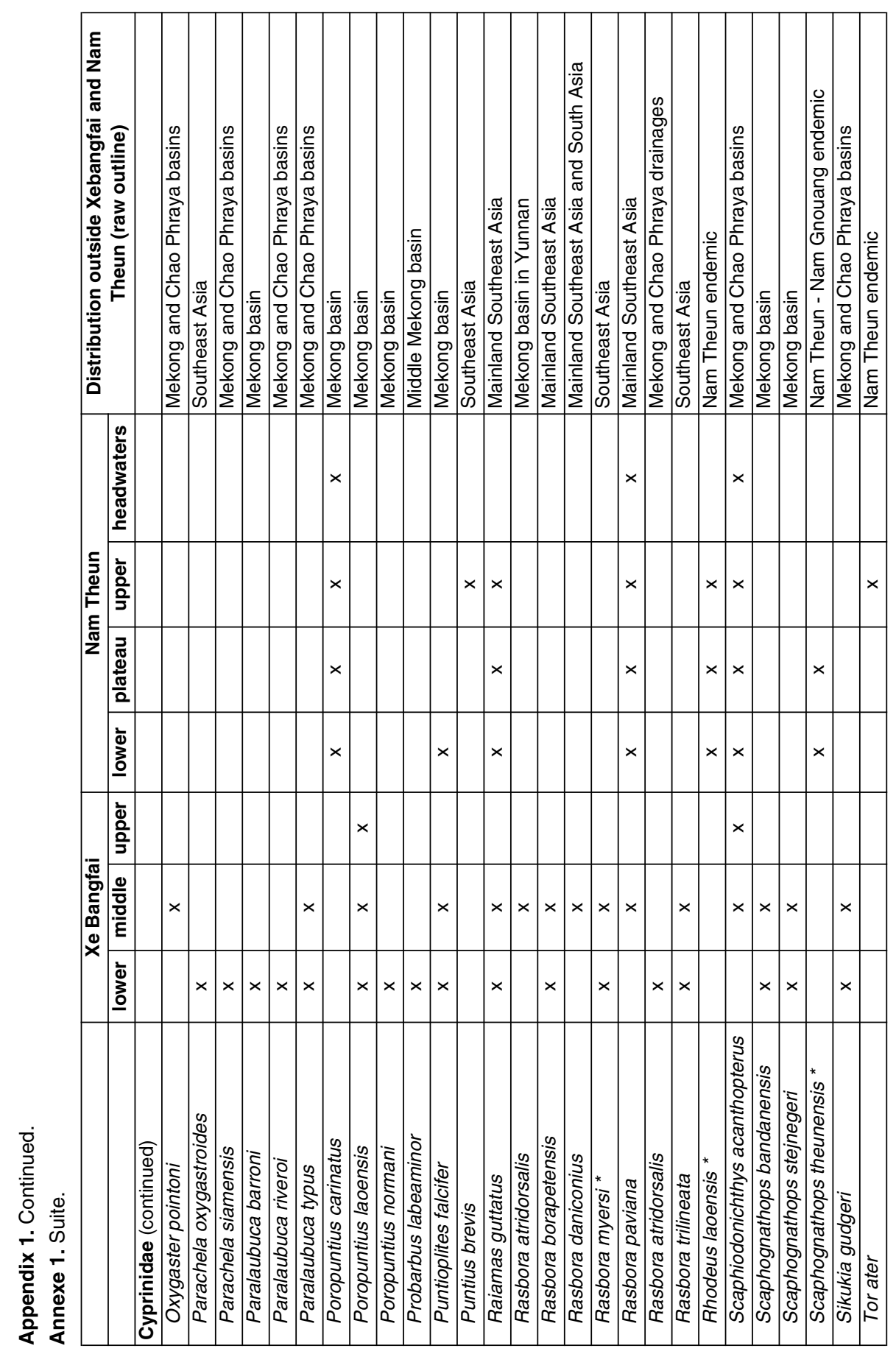



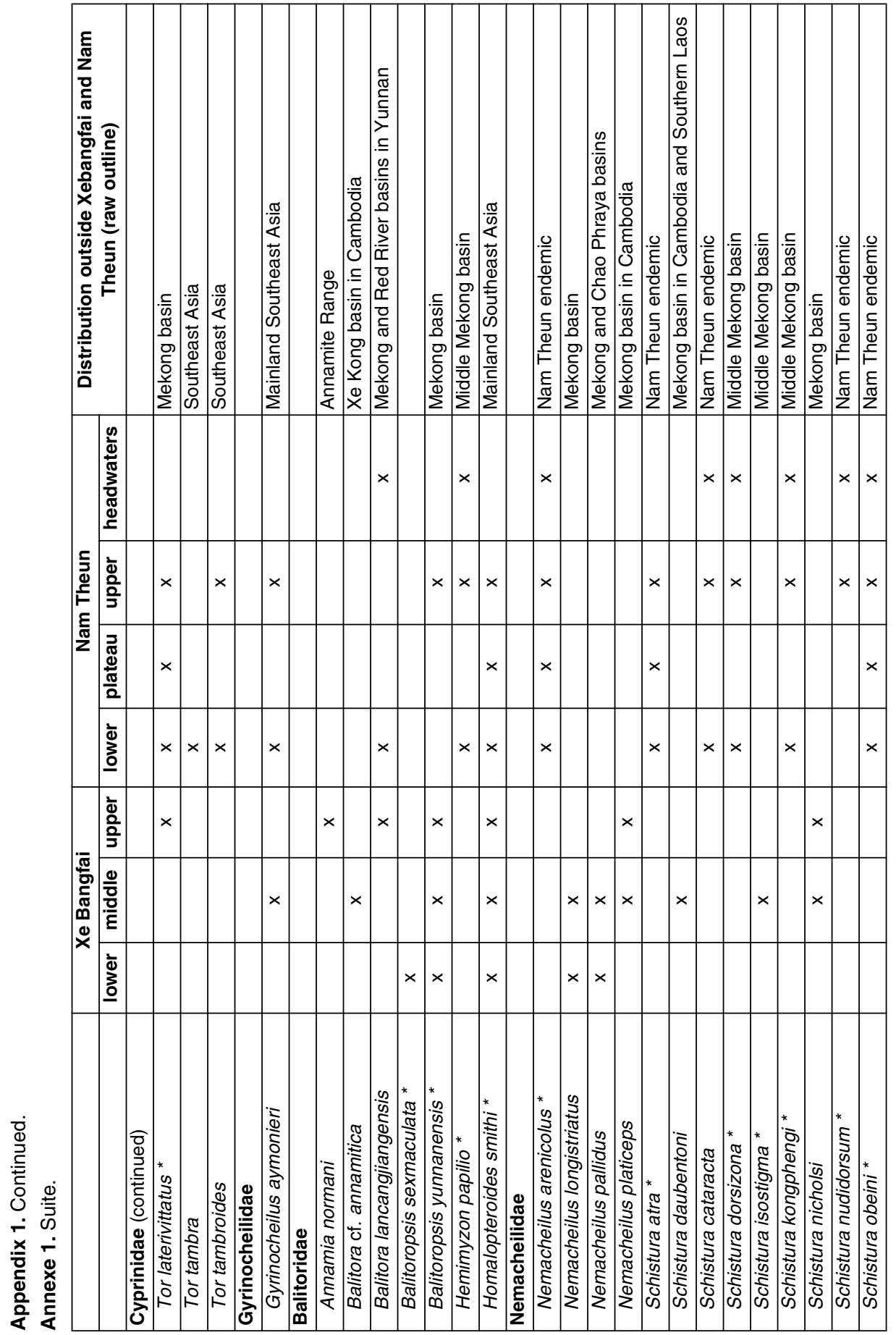


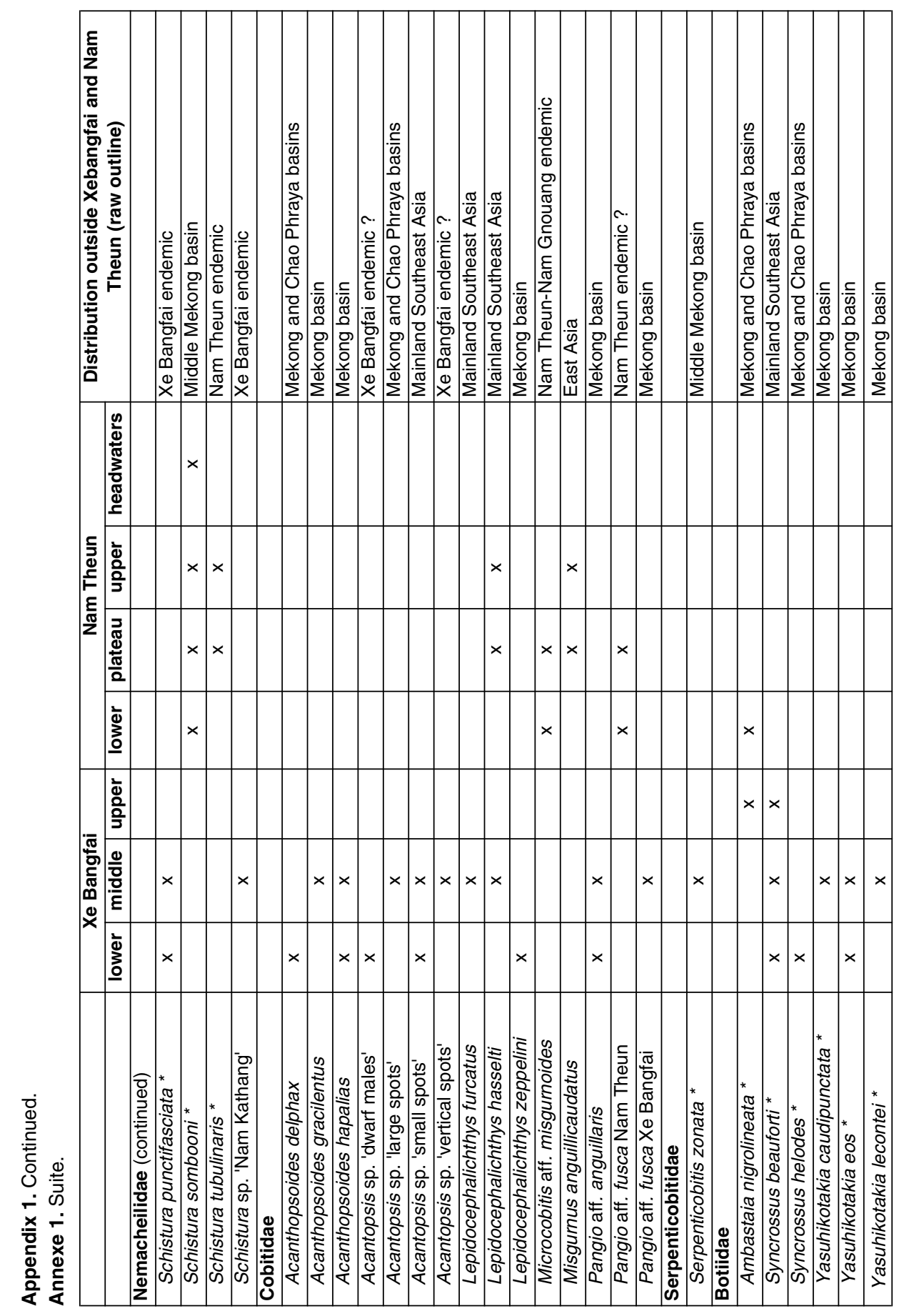




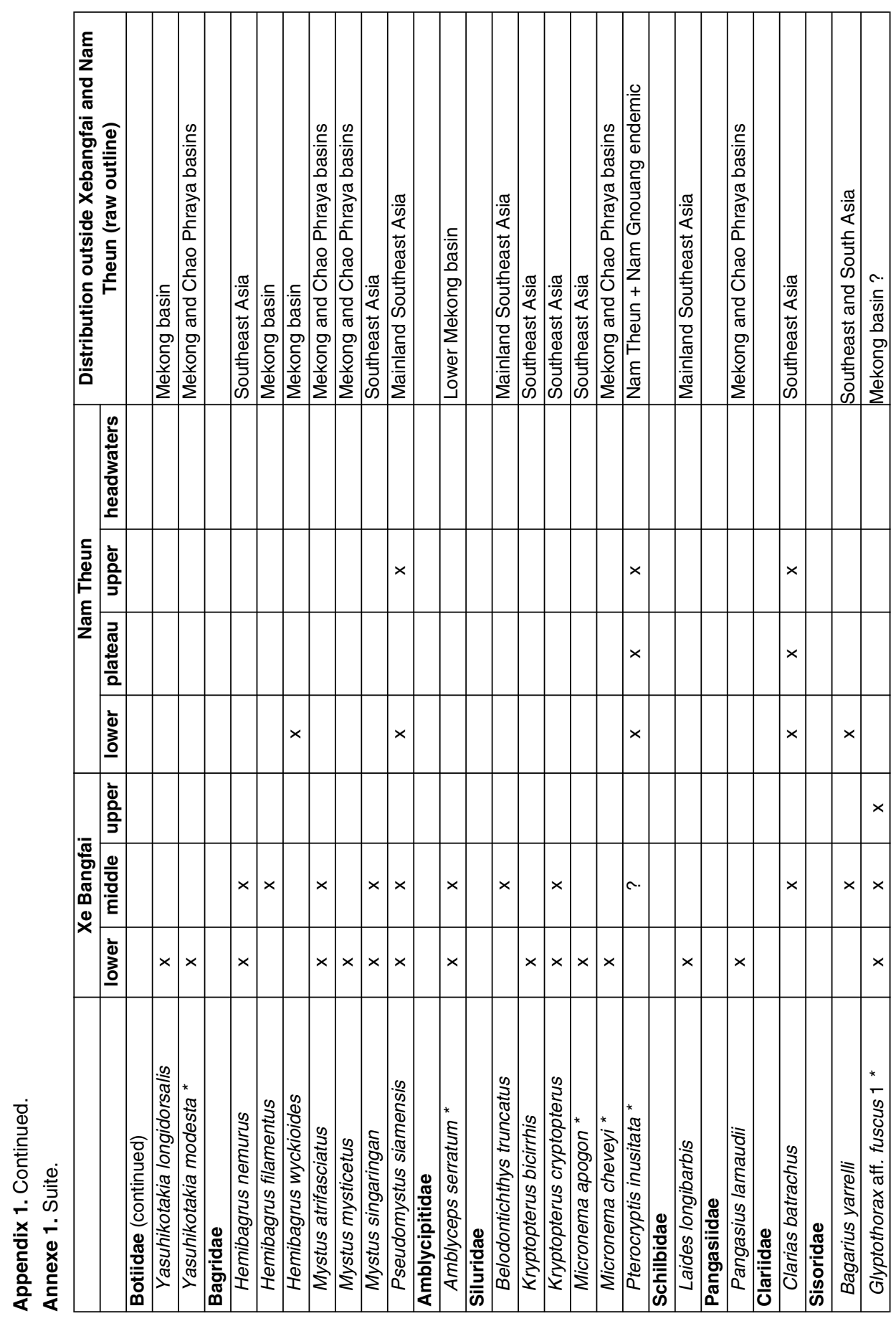



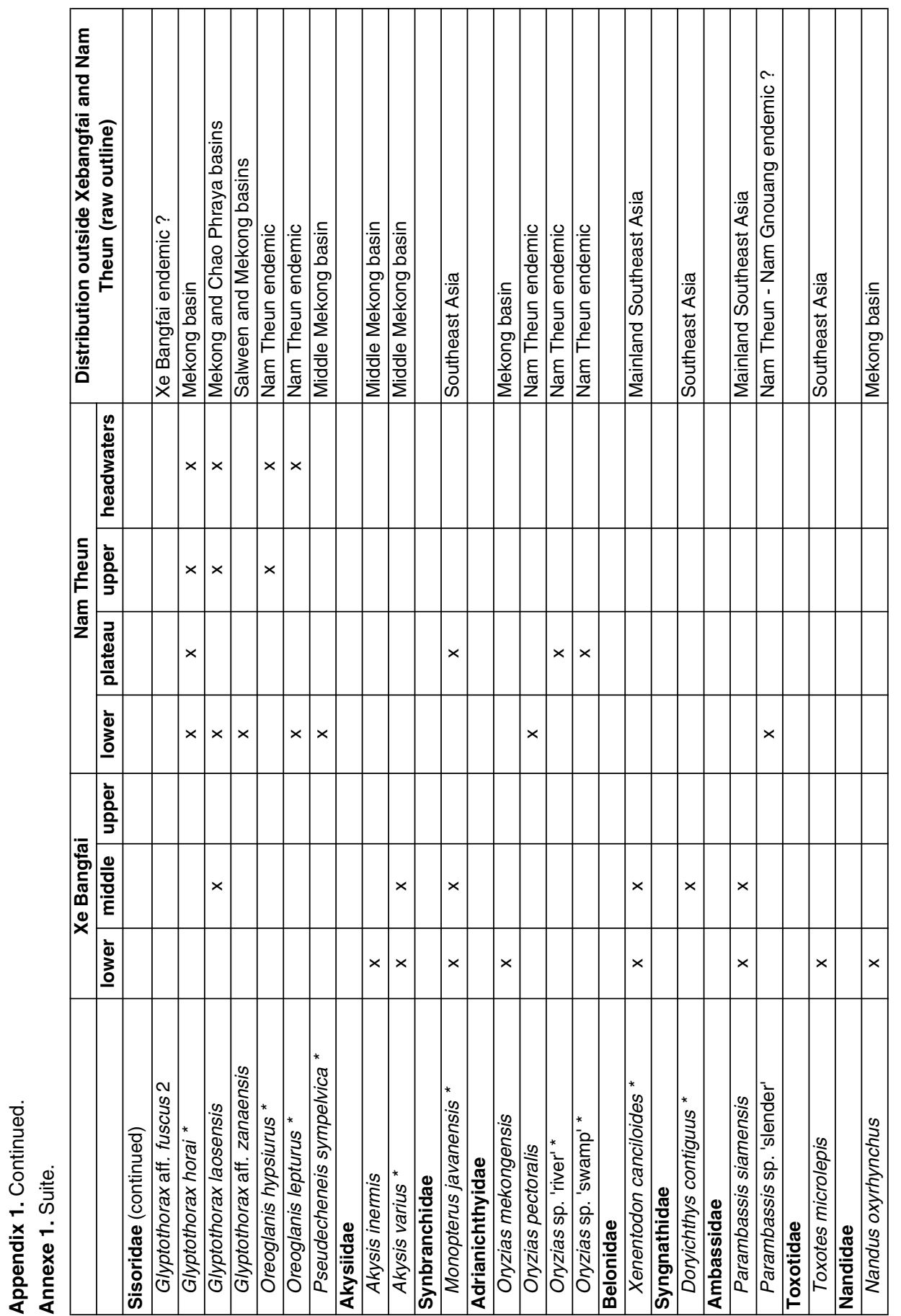
The fishes of the Nam Theun and Xe Bangfai drainages, Laos

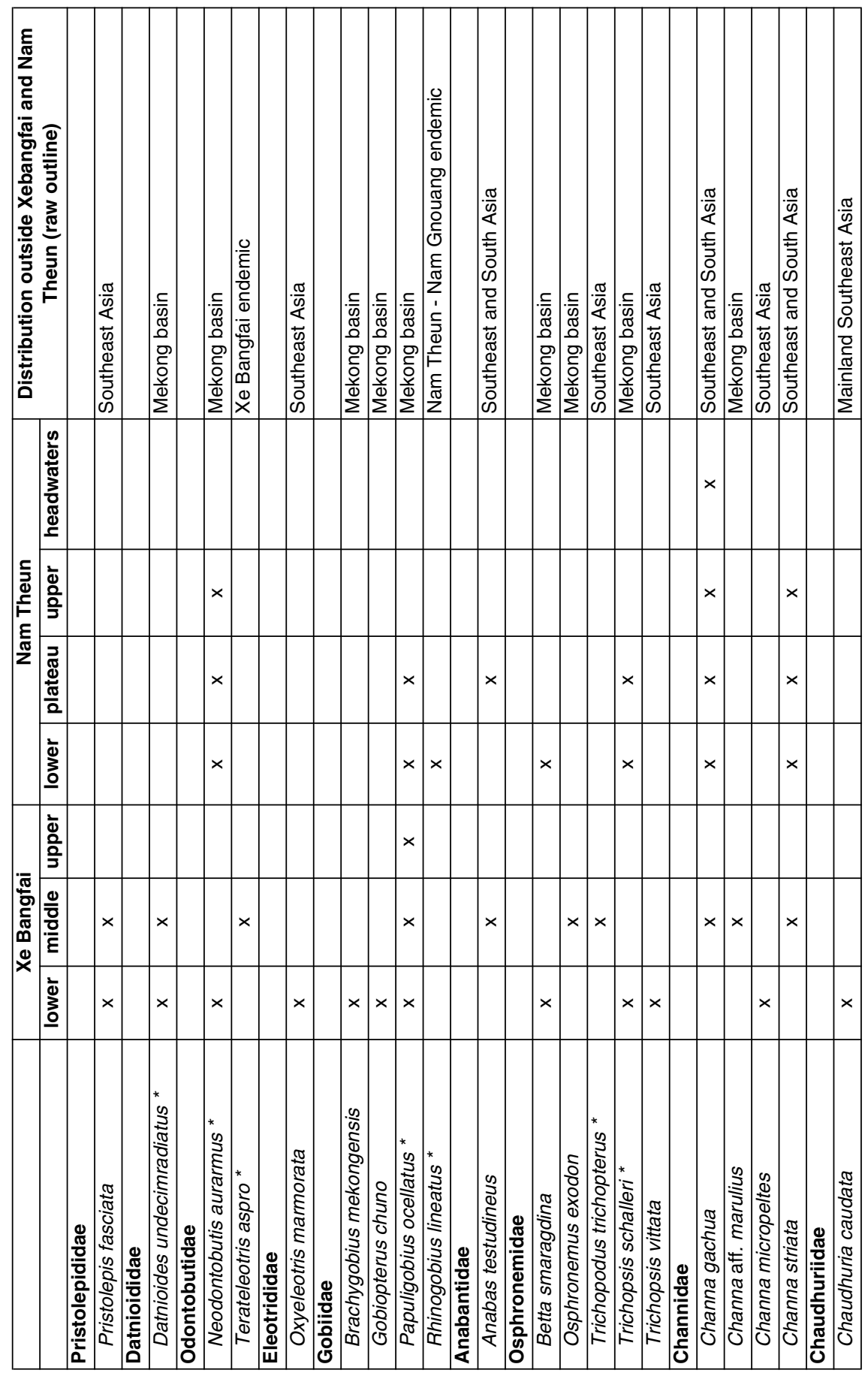




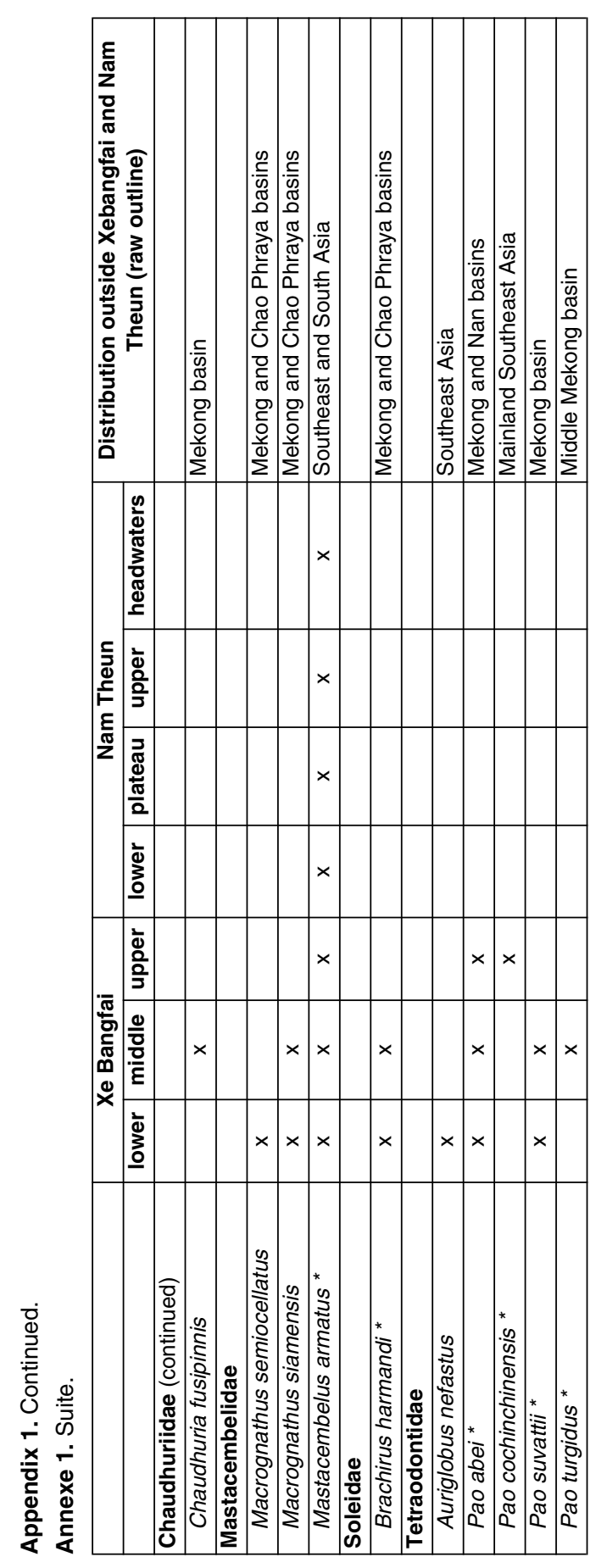


Appendix 2. Species appearing under a different name in earlier reports, publication and in Kottelat (2001).

Annexe 2. Espèces apparaissant sous un nom différent dans de précédents rapports, publication et dans Kottelat (2001).

\begin{tabular}{|c|c|}
\hline Present name & Earlier name \\
\hline Akysis varius & Akysis sp. n. aff. heterurus \\
\hline Ambastaia nigrolineata & Botia cf. nigrolineata, Yasuhikotakia nigrolineata \\
\hline Amblyceps serratum & Amblyceps sp. $\mathrm{n}$. aff. mangois \\
\hline Bangana elegans & Bangana sp. n. aff. sinkleri \\
\hline Barbodes aurotaeniatus & Puntius aurotaeniatus \\
\hline Barbodes jacobusboehlkei & Puntius jacobusboehlkei \\
\hline Barbodes rhombeus & Puntius rhombeus \\
\hline Barbonymus altus & Barbodes altus \\
\hline Barbonymus gonionotus & Barbodes gonionotus \\
\hline Barbonymus schwanenfeldii & Barbodes schwanenfeldii \\
\hline Brachirus harmandi & Euryglossa harmandi \\
\hline Crossocheilus oblongus & Crossocheilus siamensis \\
\hline Datnioides undecimradiatus & Coius undecimradiatus \\
\hline Devario fangfangae & Danio aff. strigillifer \\
\hline Doryichthys contiguus & Doryichthys deokhatoides \\
\hline Garra theunensis & Garra cf. pingi \\
\hline Glyptothorax aff. fuscus 1 & Glyptothotrax lampris \\
\hline Glyptothorax horai & Glyptothorax macromaculatus \\
\hline Hemimyzon papilio & Hemimyzon sp. n. aff. elongata \\
\hline Hypsibarbus vernayi & Barbodes daruphani \\
\hline Labeo pierrei & Labeo yunnanensis \\
\hline Laides longibarbis & Laides hexanema \\
\hline Laubuka laubuca & Chela laubuca \\
\hline Mastacembelus armatus & Mastacembelus armatus and M. favus \\
\hline Micronema apogon & Kryptopterus apogon \\
\hline Micronema cheveyi & Kryptopterus cheveyi \\
\hline Monopterus javanensis & Monopterus albus \\
\hline Nemacheilus arenicolus & Nemacheilus sp. $\mathrm{n}$. aff. pallidus \\
\hline Neodontobutis aurarmus & Odontobutis aurarmus \\
\hline Neolissochilus blanci & Neolissochilus stracheyi \\
\hline Onychostoma fusiforme & Onychostoma cf. elongata \\
\hline Onychostoma meridionale & Onychostoma sp. n. cf. elongata \\
\hline Opsarius koratensis & Barilius koratensis \\
\hline Opsarius pulchellus & Barilius pulchellus \\
\hline Oreoglanis lepturus & Oreoglanis delacouri (in part) \\
\hline Oreoglanis hypsiurus & Oreoglanis delacouri (in part) \\
\hline Oryzias pectoralis & Oryzias sinensis (in part) \\
\hline Oryzias sp. 'river' & Oryzias sinensis (in part) \\
\hline Oryzias sp. 'swamp' & Oryzias sinensis (in part) \\
\hline
\end{tabular}


Appendix 2. Continued.

Annexe 2. Suite.

\begin{tabular}{|c|c|}
\hline Present name & Earlier name \\
\hline Osteochilus striatus & Osteochilus sp. n. aff. sarawakensis \\
\hline Osteochilus vittatus & Osteochilus hasselti \\
\hline Pao abei & Tetraodon sp. $\mathrm{n}$. yellow spots \\
\hline Pao suvattii & Tetraodon suvattii \\
\hline Papuligobius ocellatus & Rhinogobius ocellatus \\
\hline Pseudecheneis sympelvica & Pseudecheneis sp. $\mathrm{n}$. \\
\hline Pterocryptis inusitata & Pterocryptis cochinchinensis \\
\hline Rasbora myersi & Rasbora dusonensis \\
\hline Rhinogobius lineatus & Rhinogobius mekongianus \\
\hline Rhodeus laoensis & Rhodeus sp. $\mathrm{n}$. aff. spinalis \\
\hline Scaphognathops theunensis & Scaphognathops sp. n. red caudal \\
\hline Schistura atra & Schistura sp. n. black \\
\hline Schistura dorsizona & Schistura sp. n. saddles \\
\hline Schistura isostigma & Schistura geisleri \\
\hline Schistura kongphengi & Schistura cf. kengtungensis \\
\hline Schistura nudidorsum & Schistura sp. n. naked back \\
\hline Schistura obeini & Schistura sp. n. red tail \\
\hline Schistura punctifasciata & Schistura sp. n. narrow bars \\
\hline Schistura sombooni & Schistura aff. breviceps \\
\hline Schistura tubulinaris & Schistura sp. n. tubular naris \\
\hline Serpenticobitis zonata & new genus new species \\
\hline Sundasalanx mekongensis & Sundasalanx aff. microps \\
\hline Syncrossus beauforti & Botia beauforti \\
\hline Syncrossus helodes & Botia helodes \\
\hline Terateleotris aspro & Odontobutis sp. $\mathrm{n}$. \\
\hline Tor laterivittatus & Tor sp. n. red fins \\
\hline Toxotes microlepis & Toxotes chatareus \\
\hline Trichopodus trichopterus & Trichogaster trichopterus \\
\hline Xenentodon canciloides & Xenentodon sp. n. large scales \\
\hline Yasuhikotakia caudipunctata & Botia caudipunctata \\
\hline Yasuhikotakia eos & Botia eos \\
\hline Yasuhikotakia lecontei & Botia lecontei \\
\hline Yasuhikotakia modesta & Botia modesta \\
\hline Yasuhikotakia longidorsalis & Botia longidorsalis \\
\hline
\end{tabular}

